\title{
Historyczne obiekty sportowe Warszawy jako walor turystyki współczesnej Część l: od średniowiecza do wybuchu II wojny światowej
}

\section{Anna Pawlikowska-Piechotka, Maciej Piechotka}

\section{STRESZCZENIE}

Historia obiektów sportowych Warszawy jest wpisana w dzieje miasta i stanowi dokument jego dziedzictwa kulturowego. Od kilkuset lat rozwojowi poszczególnych dyscyplin sportu uprawianych w Warszawie towarzyszą inwestycje dla sportu, widoczna jest ewolucja budownictwa sportowego. Zatem historia warszawskiej architektury sportowej obejmuje okres około siedmiuset lat: od średniowiecza po czasy współczesne. Były to zarówno budowle wznoszone na potrzeby wielkich imprez sportowych, jakimi były tory wyścigowe i są współczesne stadiony, jak i obiekty sportowe towarzyszące oświacie czy codziennej rekreacji mieszkańców miasta.

Zarówno te, które przetrwały do naszych czasów, jak i te już nieistniejące, są ważnym dokumentem historii miasta, symbolem jego tożsamości i mogą być podstawą rozwoju turystyki kulturowej w Warszawie, opartej o materialne (obiekty zachowane) i niematerialne (pamięć historyczna) walory.

Słowa kluczowe: Warszawa, obiekty sportowe, zabytki, turystyka kulturowa

\section{Wprowadzenie}

Historia obiektów sportowych Warszawy jest wpisana w dzieje miasta i stanowi dokument jego dziedzictwa kulturowego. Od kilkuset lat rozwojowi poszczególnych dyscyplin sportu uprawianych w Warszawie towarzyszą inwestycje dla sportu, widoczna jest ewolucja budownictwa sportowego. Zatem historia warszawskiej architektury sportowej obejmuje około siedmiuset lat: od średniowiecza po czasy współczesne. Były to zarówno budowle wznoszone na potrzeby wielkich imprez sportowych, jakimi były tory wyścigowe i są współczesne stadiony, jak i obiekty sportowe towarzyszące oświacie czy codziennej rekreacji mieszkańców miasta.

Należy zastrzec, że nie wszystkie obiekty sportowe, szczególnie powstałe w czasach odległych, przetrwały do naszych czasów, a wiele spośród tych, które udało się zachować jest głęboko zmodernizowanych i przebudowanych. Tym cenniejsze są te, które przetrwały w niezmienionym, pierwotnym stanie. 
Wiele z historycznych i współczesnych obiektów sportowych w Warszawie to budowle wybitne, dokumentujące niezwykłe osiągnięcia w zakresie kompozycji architektonicznej i inżynierskich konstrukcji. Przykładem są obiekty z kolejnych epok historycznych:

- neoklasycystyczna ujeżdżalnia w Wilanowie autorstwa Franciszka Lanciego z 1848 r. (dzisiaj- Muzeum Plakatu);

- w stylu modernizmu typowego dla II RP zachowały się trybuny Torów Służewieckich, autorstwa Zygmunta Platera-Zyberka z 1938 r., zespół CIWF na Bielanach, autorstwa Edgara Norwertha z 1930 r. Kampus uczelni CIWF (AWF) został uzupełniony po II wojnie światowej eleganckimi obiektami w stylu modernizmu charakterystycznymi dla II połowy XX w. (pawilony sportów walki, hala gier) projektu Wojciecha Zabłockiego;

- w stylu socrealizmu zachował się budynek frontowy KS Polonii, autorstwa Juliana i Danuty Brzuchowskich z 1954 r.

Warto podkreślić, że Stadion Narodowy, wzniesiony z okazji organizacji w Polsce mistrzostw EURO 2012 w miejscu Stadionu X-lecia PRL, już stał się popularną wizytówką miasta. Jest obecnie wymieniany, obok symboli tradycyjnych, jakimi są od dawna Kolumna Zygmunta, Pomnik Syreny, Zamek Królewski czy PKiN, jako nowy, silny i rozpoznawalny znak identyfikacyjny Warszawy.

Celem naszych poszukiwań badawczych na temat historii budownictwa sportowego w Polsce, których częścią były dzieje budowli sportowych w Warszawie, była chęć przedstawienia $\mathrm{w}$ jednym ujęciu uporządkowanych informacji z wielu rozproszonych źródeł na temat znaczących osiągnięć polskiego budownictwa dla sportu w przekroju historycznym, przypomnienie projektów polskich architektów i inżynierów konstruktorów, także tych koncepcji, których nie udało się zrealizować. Dla takiego ujęcia tematu przyjęto metodę opisowa, opartą przede wszystkim na analizie zebranego materiału faktograficznego, krytycznym przeglądzie literatury przedmiotu i dokumentów archiwalnych. Stąd nasze prace były oparte przede wszystkim o kwerendę biblioteczną w zbiorach naukowych i archiwach (Wydział Architektury Politechniki Warszawskiej, Akademia Wychowania Fizycznego Józefa Piłsudskiego w Warszawie, Instytut Sztuki PAN, Muzeum Historyczne m.st. Warszawy, Muzeum Narodowe w Warszawie, Muzeum Architektury we Wrocławiu, Muzeum Sportu i Turystyki w Warszawie, Muzeum Stadionu Narodowego, Muzeum KS Legii) oraz towarzystw sportowych (Warszawskie Towarzystwo Cyklistów, Warszawskie Towarzystwo Żeglarskie), w mniejszym stopniu o badania historyczno-terenowe.

\section{Styl, program i funkcja obiektów sportowych}

Architektura obiektów sportowych jest niezwykle różnorodna. Ta rozmaitość objawia się zarówno w wielorakich stylach i formach, charakterystycznych dla epoki, w której je wznoszono, jak i treściach programowych, funkcji obiektu, cech środowiska i krajobrazu, społecznych oczekiwań, a także możliwości realizacji i sytuacji politycznej. Zatem od mody i potrzeb, od dyscypliny sportu i reguł gry, zależą lokalizacja, kształt, rozmiary, a również program obiektu sportowego. Niezmienna natomiast w każdej epoce była w Warszawie 
sama potrzeba wznoszenia obiektów sportowych, ich wielka przydatność dla społeczeństwa, powszechne zaangażowanie $w$ proces ich powstawania i tradycja niezwykle silnego przeżywania emocji sportowych. Niektóre obiekty sportowe są dla danej funkcji specjalnie zaprojektowane i wzniesione, inne z góry zakładają przede wszystkim ze względów ekonomicznych, także wykorzystanie - stałe lub okazjonalne - w innych celach. Racjonalizowanie wielostronnego wykorzystania obiektu sportowego wiąże się zarówno ze znacznymi kosztami zakupu działki, budowy, wysiłku jego późniejszego utrzymania, jak i społecznymi korzyściami takiego rozwiązania. Tak się dzieje z wieloma współcześnie wznoszonymi obiektami monumentalnymi: stadionami i halami widowiskowo-sportowymi (Katowicki 'Spodek', Hala Olivia, Stadion Narodowy w Warszawie) [Pawlikowska-Piechotka 2017].

\section{Wieki średnie i okres odrodzenia}

W okresie wczesnego średniowiecza w Warszawie, tak jak i innych miastach Europy, na zamku książęcym organizowano turnieje rycerskie, w podmiejskich lasach polowano, na błoniach pod murami miasta jeżdżono konno i organizowano zawody w strzelectwie, zapasach, być może pływackie i wioślarskie - jednak nie stawiano specjalnych obiektów sportowych. Dla współzawodnictwa sportowego wykorzystywano przede wszystkim podmiejskie warunki naturalne, a także ulice i place miejskie. Na przykład otoczony murami, brukowany dziedziniec Zamku Królewskiego, tak jak wyłożone cegłą dziedzińce klasztorne i place przed kościołami były wygodnymi i bezpiecznymi terenem gier zespołowych.

Turnieje rycerskie były organizowane na łąkach poza murami miasta (błoniach) lub na obszernym zamkowym dziedzińcu. Młodzi chłopcy grali drużynowo w piłkę na rynku, (po zamknięciu kramów lub w dni świąteczne, kiedy handel był zakazany), na placach przykościelnych lub organizowali współzawodnictwo polegające na wykorzystaniu do gry siatki ulic i przenoszeniu piłki z jednej bramy miejskiej do drugiej.

W dni świąteczne na łąkach podmiejskich organizowano zawody strzeleckie, biegi (ze sztafetą), gry zręcznościowe i tańce, co nie wymagało kłopotliwych przygotowań ani wznoszenia specjalnych budowli [Bogucka 1998, 2008; Lipoński 2012; Pawlikowska-Piechotka 2014].

\section{Oświecenie i klasycyzm}

Ten okres, potocznie określany także jako 'wiek rozumu', przyniósł znaczące zmiany w systemie szkolnictwa i wychowania w całej Polsce, także w Warszawie. Polowania, turnieje rycerskie, bractwa strzeleckie i gry ludowe wydawały się niewystarczające wobec antycznych osiągnięć w tym zakresie, szczególnie w porównaniu ze starożytną Grecją. Kształtując programy nauczania młodzieży wzorowano się na ideale greckim gimnazjonu, nacisku na równoległy rozwój duchowy i fizyczny. Takie programy miały szkoły i kolegia w Anglii, Niemczech i Danii, a także polskie - kształcące zgodnie z najnowszymi prądami pedago- 
gicznymi. Pierwszym zakładem naukowym o tak prekursorskim programie było Collegium Nobilium w Warszawie założone przez Stanisława Konarskiego w 1740 r. W programach Komisji Edukacji Narodowej, wychowanie fizyczne młodzieży było zaznaczone jako niezbędny element, w tym podkreślono rolę nauki pływania. W warszawskim Collegium Nobilium przy ulicy Miodowej (wzniesionego wg projektu Jakuba Fontany w 1743 r.) mieściło się kilka sal gimnastycznych i pierwsze w Warszawie dwie kryte ujeżdżalnie (maneże) [Karpowicz 1986; Kwiatkowski 1984, 1986]. Dwa dziedzińce wewnętrzne szkoły służyły jako boiska do ćwiczeń [Ordyłowski1997]. Kolejną krytą ujeżdżalnią była zbudowana na ulicy Oboźnej około 1769 r. przy Pałacu Karasia, w którym mieścił się Korpus Królewskich Paziów. W XIX w. ujeżdżalnię rozebrano i wybudowano na tym miejscu kamienicę. Następne budynki maneży, na ogół drewniane, powstawały w kolejnych dekadach XIX w. przy koszarach wojskowych. W latach 1819-1823 w Ogrodzie Saskim wzniesiono maneż wg projektu wybitnego architekta epoki klasycyzmu, Jakuba Kubickiego (autora m.in. projektów przebudowy Pałacu Belweder i Pałacu Królewskiego w Warszawie). Był to elegancki, o bogatych formach dekoracyjnych i rzeźbiarskich budynek. Ściany elewacji dłuższych były ozdobione sześciokolumnowymi portykami doryckimi, zwieńczonymi trójkątnymi szczytami. Ściany szczytowe były udekorowane dwukolumnowymi portykami wgłębnymi, okna miały kształt półkola. W 1877 r. Witold Lanci przeprojektował maneż na pierwszą w Warszawie siedzibę giełdy. Od schyłku XVIII w. kryte ujeżdżalnie powstawały także przy miejskich pałacach magnackich, jak do dzisiaj zachowany obiekt przy rezydencji w Wilanowie (projekt Franciszka Lanciego), służący obecnie jako Muzeum Plakatu (pełni tę nową funkcję od 1960 r., projekt Halina Kossuth, Jacek Cydzik) [Leśniakowska 2005] (ryc. 1).

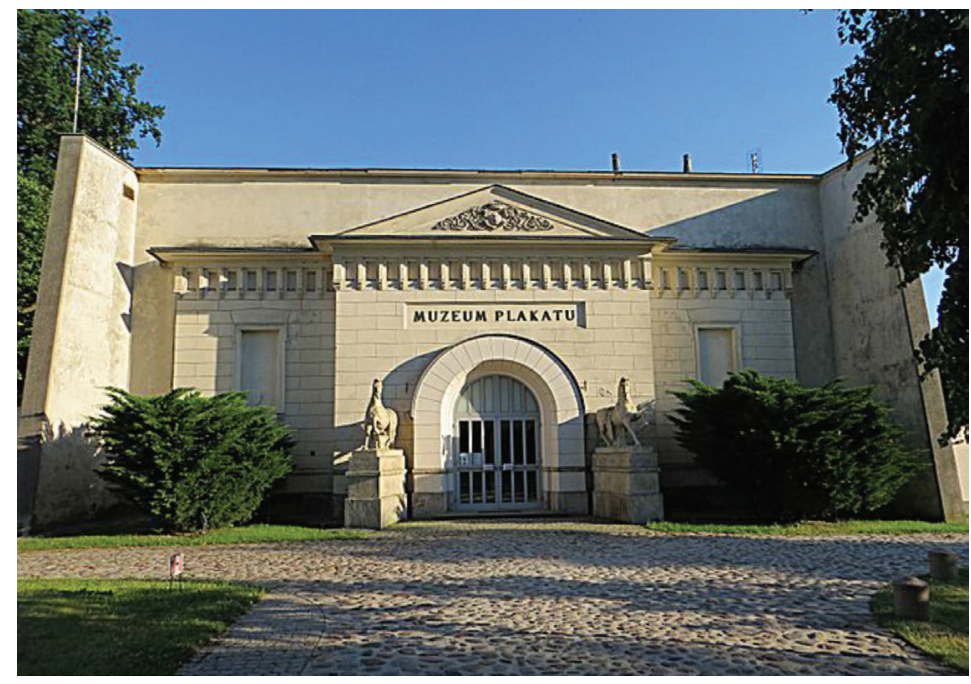

Ryc. 1. Muzeum Plakatu w Wilanowie, część Rezydencji Królewskiej Wilanów Muzeum powstało w neoklasycystycznej ujeżdżalni zespołu pałacu (proj. Franciszek Maria Lanci, ok. 1848)

Źródło: pl.wikipedia.org 
Innym przykładem jest kryta ujeżdżalnia zaprojektowana przez Szymona Bogumiła Zuga dla rezydencji Kazimierza Poniatowskiego Na Książęcym, ten maneż nie istnieje od 1936 r. [Kwiatkowski 1984]. Kolejny maneż wzniesiono w latach 1823-1824 przy pałacyku Belweder, także wg projektu Jakuba Kubickiego. Elewacje ujeżdżalni z pozoru mogłyby wydawać się reprezentacyjne dla stylu klasycystycznego - boniowanie w poziome pasy, ale okna zamknięto łukiem gotyckim, co przesądziło o innym kostiumie stylowym [Koch 1996]. Jak podkreśla Marek Kwiatkowski, belwederski maneż był pierwszym w Warszawie sygnałem nowego stylu - eklektyzmu, architektury wielostylowej, która wypierając spokojny klasycyzm, zdominowała późniejsze dekady XIX w. w całej Europie [Watkin 2005]. Budynek belwederskiej eklektycznej ujeżdżalni jest zachowany, chociaż wielokrotnie przekształcany stracił już swój pierwotny charakter [Kwiatkowski 1986]. Na wzór londyńskich, paryskich i wiedeńskich parków miejskich z bogatym programem sportowo-rekreacyjnym - założono w końcu XVIII w. parki rozrywki na Dynasach na Powiślu, Saskiej Kępie, Foksal, Bielanach i na Woli (Ogród Ohma). Były ogrodami publicznymi, wzbogaconymi o program urządzeń i organizowanych atrakcji. Wstęp do nich był wolny, czas umilali akrobaci i popisujący się wspinaczką na wysoki maszt, można było tańczyć lub posłuchać muzyki, pograć w piłkę, strzelać z łuku lub broni palnej na strzelnicy [Drozdowski, Zahorski 1981].

\section{Wiek XIX - eklektyzm}

Pierwszy polski podręcznik do gry w tenisa - Przewodnik do gry Lawn Tennis pióra A. Wodniakowskiego, ukazał się nakładem autora w 1896 r. w Warszawie. W całej Polsce sekcje tenisowe powstawały przy klubach 'Sokoła', łyżwiarskich i cyklistów. Pierwszy turniej tenisowy w Warszawie miał miejsce na kortach w Dolinie Szwajcarskiej w 1898 r. W końcu XIX w. klub tenisowy na warszawskiej Agrykoli chlubił się 6 kortami betonowymi, szatnia, bufetem, mleczarnią w sezonie letnim w namiocie oraz wielką techniczną nowinka, jaką był telefon. W 1878 r. powstało Warszawskie Towarzystwo Wioślarskie, zalegalizowane w 1882 r., dzięki staraniom m.in. Bolesława Prusa. Pierwszą przystanią była barka zacumowana u wylotu ulicy Bednarskiej [Janiszewska 2012].Warszawskie Towarzystwo Wioślarskie (WTW) początkowo miało przystań na drewnianym pontonie $\mathrm{w}$ rejonie mostu Kierbedzia (1882), ale już w 1883 r. postawiono lekki parterowy drewniany budynek klubowy z charakterystyczną wieżyczką i tarasem widokowym (proj. Jan Hinz) (ryc. 2). Obiekt był osadzony

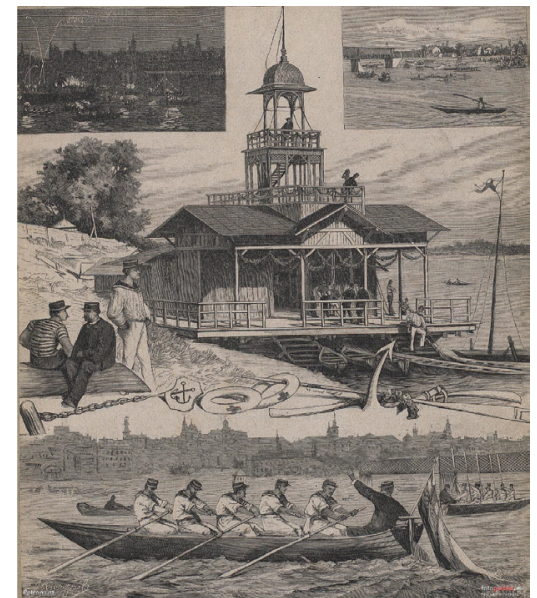

Ryc. 2. Warszawskie Towarzystwo Wioślarskie WTW; Stara przystań na Wiśle w Warszawie, koniec XIX w.

Źródło: (autor nieznany, ok. 1890), archiwum cyfrowe fotografii fotopolska.eu 
na wiślanym szerokim galarze, cumowanym do praskiego brzegu (ta drewniana konstrukcja spłonęła w czasie pożaru w 1925). Od 1886 r. przeniesiono przystań WTW na lewy brzeg, w pobliżu Mariensztatu. W celu umożliwienia rozwoju Warszawskiego Towarzystwa Wioślarskiego, a także i uprawiania w zimie innych sportów (szermierka i gimnastyka) w $1897 \mathrm{r}$. powstał reprezentacyjny gmach przy ulicy Foksal 19. Został zaprojektowany przez Bronisława Brochwicz-Rogoyskiego, a powstał ze składek i darowizn członków klubu. Działkę gruntu przekazał hrabia Ksawery Branicki, wieloletni prezes WTW. Okazały neogotycki gmach o czterech kondygnacjach, z rzeźbą Hipolita Marczewskiego 'Alegoria Wisły' umieszczoną na frontonie stał się jednym z najpiękniejszych i eleganckich budynków ówczesnej Warszawy. Na wzór angielskich klubów, łączących eleganckie życie towarzyskie ze sportem, znajdowały się tam zarówno sale gimnastyczne i szatnie, jak restauracja i pokoje zebrań. Na drugim piętrze usytuowano wielką salę balową ozdobioną malowidłem Henryka Siemiradzkiego 'Syrena na tle Starego Miasta'. Siedziba WTW stała się wkrótce centrum życia towarzyskiego elit Warszawy, uroczystości tam organizowane opisywano w prasie, na przykład cieszące się wielkim powodzeniem słynne bale karnawałowe. Członkami Towarzystwa zostawały znane osobistości świata kultury - m.in. najwybitniejsi ówcześni literaci Bolesław Prus i Henryk Sienkiewicz ${ }^{1}$. Należy zaznaczyć, że zimą staraniem WTW organizowano ślizgawki w Ogrodzie Saskim, Parku Ujazdowskim oraz przy zbiegu ulic Nowy Świat i Foksal. W okresie letnim przy przystani organizowano kąpielisko i szkółkę pływacką [Janiszewska 2012]. W tym okresie w Warszawie działał także prestiżowy Yacht Club, należeli jednak do niego przede wszystkim mieszkający w mieście cudzoziemcy: na ogół byli to Rosjanie i Niemcy. Ze względu na obawę przed spiskami antyrządowymi i nastrojami narodowowyzwoleńczymi, władze carskie zabraniały Polakom stowarzyszania się, czyniono niechętnie wyjątki (WTC, WTW). Yacht Club Polski został oficjalnie powołany dopiero w 1924 r. [Drozdowski, Zahorski 1981]. Pierwsze kryte pływalnie powstały w Warszawie dopiero w okresie II RP, natomiast w XIX w. przy przystaniach wiślanych i nad stawami (Stawy Kellera na Bielanach) organizowano kąpieliska połączone z nauką pływania. Jedną z pierwszych w Warszawie była Wojskowa Szkoła Pływania założona przy północnym brzegu Stawu Marymonckiego (przy ówczesnej ulicy Rudzkiej), otwarta około 1829 r. [Pawłowski, Zieliński 2008]. Pierwsze wyścigi konne w Polsce o charakterze rywalizacji sportowej miały miejsce w Polsce w 1777 r. w Warszawie, na trasie rogatki Woli - Zamek Ujazdowski. Wyścigi organizowano m.in. na ulicy Marszałkowskiej (np. w 1818 r.), a nawet na niezabudowanych terenach niedaleko Łazienek Królewskich (około 1838 r). W marcu 1841 r. powstało Towarzystwo Wyścigów Konnych i Wystawy Zwierząt Gospodarskich w Królestwie Polskim. Towarzystwo miało na celu organizowanie wyścigów konnych oraz wspieranie hodowli koni rasowych. Pierwszy tor wyścigów konnych w Warszawie zlokalizowano przy ulicy Polnej w Warszawie (Pola Mokotowskie), dzięki inicjatywie Towarzystwa. Tor wyścigowy był korzystnie zlokalizowany (na rogatkach miasta), wybudowano tam stajnie, trzy drewniane trybuny i ujeżdżalnię (ryc. 3 i 4).

${ }^{1}$ Opracowano na podstawie materiałów udostępnionych przez Warszawskie Towarzystwo Wioślarskie w 2016 r. 


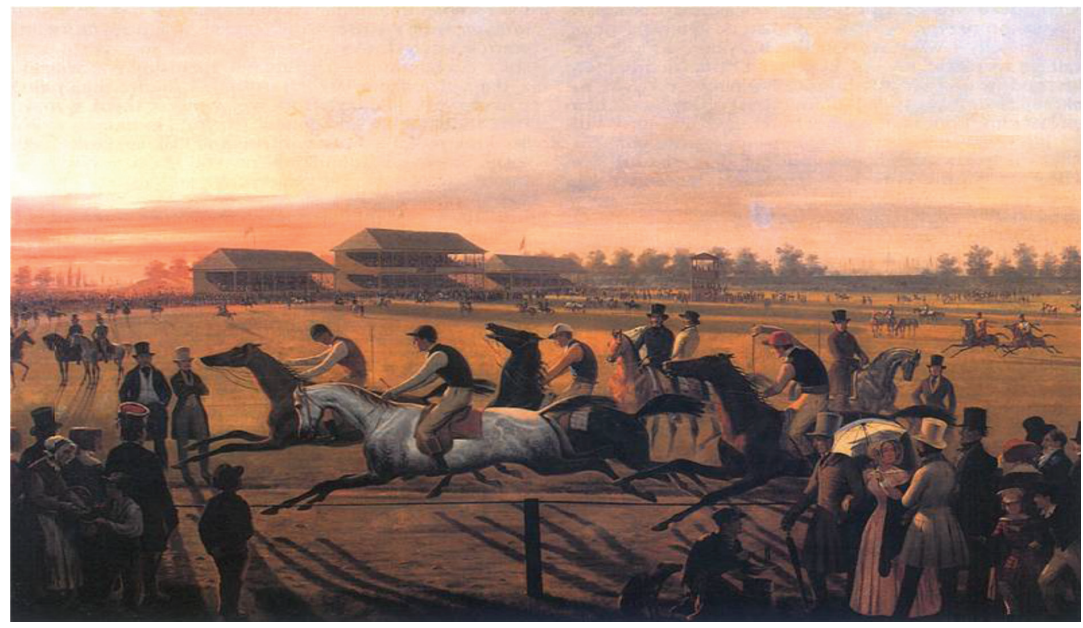

Ryc. 3. Tory wyścigowe w Warszawie na Polach Mokotowskich Na drugim planie drewniane trybuny dla widzów, I połowa XIX w.

Źródło: obraz olejny January Suchodolski: Pierwsze wyścigi na Polach Mokotowskich w Warszawie, 1849, kolekcja malarstwa polskiego w zbiorach Muzeum Narodowego w Warszawie [Domena Publiczna]

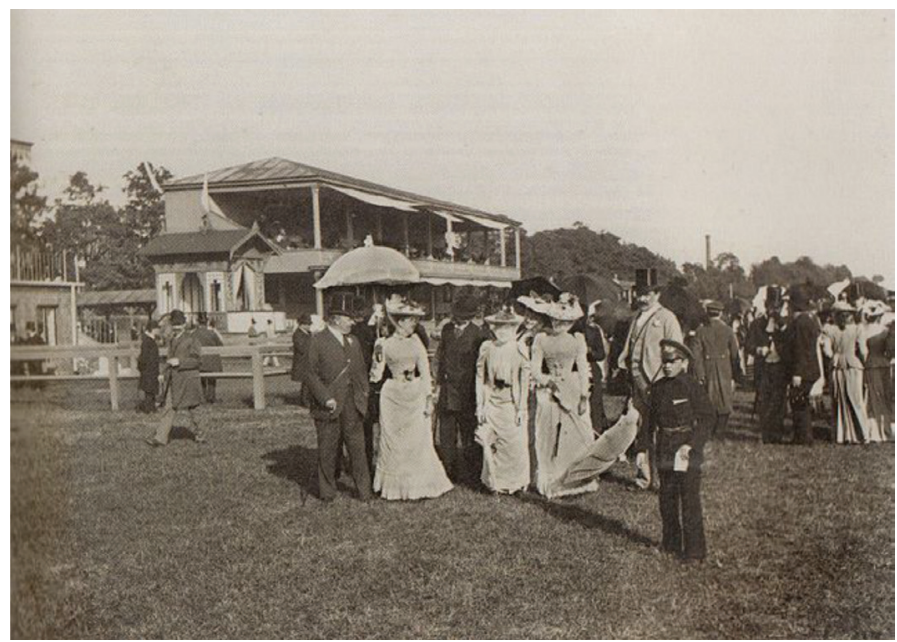

Ryc. 4. Tory wyścigowe w Warszawie na Polach Mokotowskich Na drugim planie drewniane trybuny dla widzów, II połowa XIX w. Źródło: fotografia z XIX w., Archiwum Cyfrowe fotopolska.eu [Domena Publiczna] 
Pierwsze wyścigi rozegrano już w czerwcu 1841 r. na Polach Mokotowskich (w okolicach dzisiejszego placu Unii Lubelskiej, teren był oznaczany na mapach 'mokotowskie pole wojenne'), tor wyścigowy miał długość około kilometra. W 1845 r. tor wyścigowy przesunięto w kierunku południowo-zachodnim, w pobliżu dzisiejszych ulic Wawelskiej i alei Niepodległości. Tam rozgrywano wyścigi do 1886 r., z przerwą na dwa lata, kiedy w 1863 r., wraz z wybuchem Powstania Styczniowego, zawieszono wyścigi konne 'za karę'. Ponowne przemieszczenie torów (w stronę wschodnia, w kierunku ulicy Polnej, wjazd od strony Politechniki był zaakcentowany okazałą bramą) było ostatnią przeprowadzką przed zamknięciem torów w 1938 r. i przeniesieniem wyścigów na Służewiec. Warszawskie Towarzystwo Cyklistów (WTC) zajmowało się nie tylko upowszechnianiem sportu rowerowego, ale także łyżwiarstwa, jazdy na wrotkach i gimnastyki. Pierwszą siedzibą WTC był parterowy budynek przy ulicy Marszałkowskiej 57 (róg Koszykowej). Obok pomieszczeń klubowych, wzniesiono dobrze wyposażoną salę gimnastyczną i pod nazwą Koła Gimnastycznego WTC prowadzono zakonspirowaną działalność Sokoła (zabronionego pod zaborem rosyjskim). Wkrótce działalność rozszerzono o sekcję tenisa ziemnego i krokieta [Tuszyński 1986]. W 1892 r. WTC przeniosło się do nowej siedziby - do pałacyku na Dynasach, przy którym wzniesiono pierwszy w Warszawie 'tor cyklowy' (welodrom), którego wewnętrzna część służyła zimą jako ślizgawka. Uroczy parterowy budynek klubowy, o XIX-wiecznym eklektycznym stylu typowym dla podmiejskiej architektury w końcu XIX w. był dziełem wziętego wówczas warszawskiego architekta - Stefana Schillera (autora m.in. Gmachu Głównego Politechniki Warszawskiej). Tak zwany Pałacyk na Dynasach, był pełną wdzięku budowlą z drewnianymi lożami, wieżyczką i dwukondygnacyjnym korpusem środkowym, miał nieco kurortowy charakter, bardzo pasujący do otoczonego bujną zielenią zespołu sportowego, położonego w spokojnym miejscu na Skarpie, z dala od centrum miasta. Obiekt, poza salą zebrań służącą także jako koncertowa, bufetem, czytelnia, szatniami i pomieszczeniami administracyjnymi miał oddzielny salonik dla dam. Z drewnianej wieżyczki roztaczała się panorama widokowa na Dolinę Wisły. Ważną częścią budynku klubowego była obszerna i dobrze wyposażona sala gimnastyczna, wykorzystywana także do gry w tenisa i urządzanych tam balów. Tuż obok była remiza do przechowywania około 200 rowerów i tor kolarski. Z czasem przy zespole sportowym WTC Dynasy powstało jeszcze boisko sportowe do gry w piłkę nożną. Budynek klubowy w 1926 r. został zmodernizowany i powiększony, projekt zlecono Franciszkowi Szymczakowi. Początkowo tor kolarski na Dynasach był ziemny, miał owalny kształt, 383 m długości i 6 m szerokości, był dziełem inżyniera Józefa Hussa i należał wówczas do najnowocześniejszych w Europie. Wewnątrz toru kolarskiego było sztuczne jeziorko z trzema wyspami, na jednej z nich wzniesiono altankę dla orkiestry przygrywającej w czasie letnich wyścigów kolarskich lub zimowej ślizgawki. Staw wewnątrz toru służył latem wytwornym warszawskim wędkarzom (zachowało się zdjęcie archiwalne z końca XIX w., na którym wędkują na Dynasach eleganccy panowie w cylindrach) (ryc. 5). Ten szczegół wyróżniał tor kolarski w Warszawie na tle innych w Europie, które na ogół wewnątrz obwodu mieściły boiska piłkarskie. 


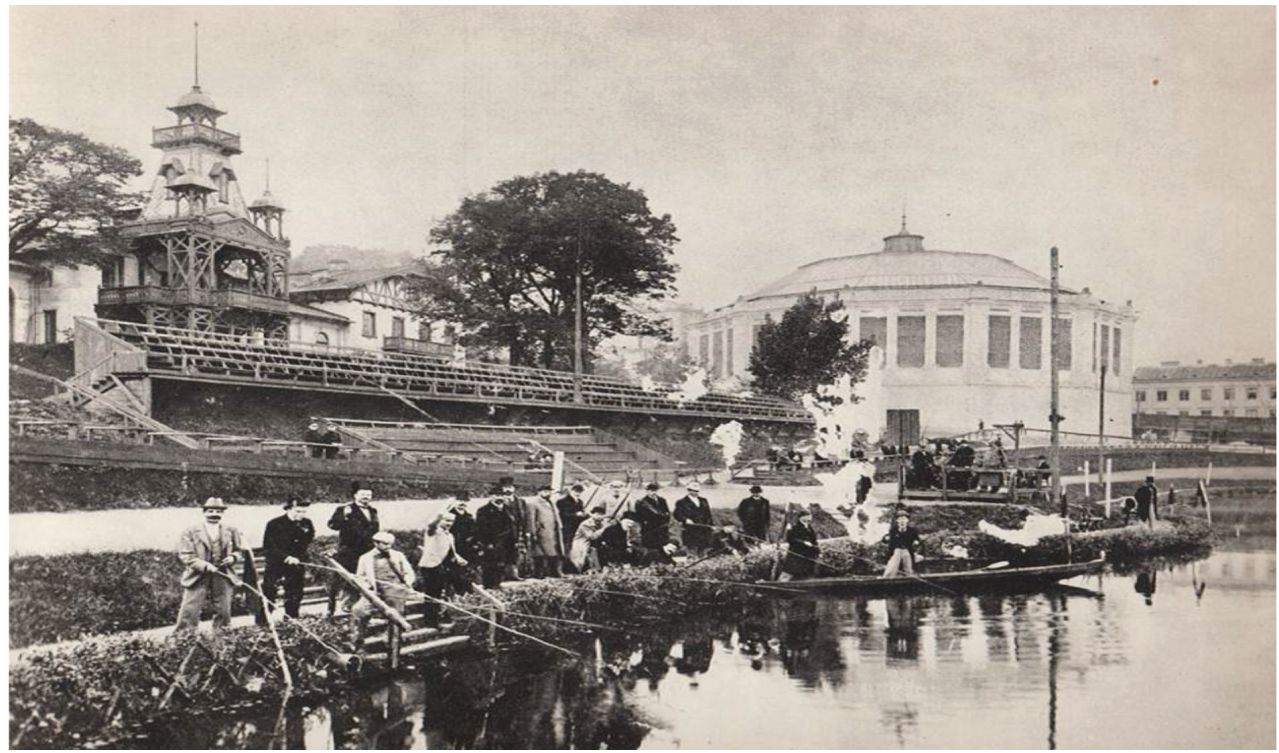

Ryc. 5. Klub Warszawskiego Klubu Cyklistów WTC, Dynasy na Powiślu Na pierwszym planie wędkarze przy jeziorku wewnątrz welodromu, wokół tor wyścigowy, na drugim planie 'Pałacyk Dynasy', siedziba klubu oraz rotunda dla pomieszczenia 'Panoramy Tatr', stan na koniec XIX w.

Źródło: Fot. E. Troczewski, 1897 [Domena Publiczna]

Tor kolarski ziemny, ceglano-żużlowy, na Dynasach przebudowano w 1920 r. na tor kolarski betonowy (długość: 385 m), czemu patronował sam Naczelnik Państwa - Józef Piłsudski. Zmodernizowany warszawski tor kolarski na Dynasach istniał do 1939 r. Na Dynasach w końcu XIX w., od strony zachodniej, wzniesiono niewielkie trybuny dla widzów z lożą honorową. Od strony północnej zespołu postawiono w 1896 r. obszerny pawilon w kształcie rotundy o wysokich oknach i namiotowym dachu, autorem projektu budowli był Karol Kozłowski (architekt, którego dziełem był gmach Filharmonii Warszawskiej). Z zachowanych w archiwum dokumentów wynika, że okazała rotunda była o 30\% kosztowniejszą inwestycją (100 tys. rubli) od budynku klubowego i toru kolarskiego razem wziętych (65 tys. rubli). Jej główną funkcją było pomieszczenie najpierw 'Panoramy Tatr' Stanisława Jankowskiego, a potem obrazu 'Trzy dni Zbawiciela' Jana Styki. Jednak pawilon prawdopodobnie służył także za bufet i szatnię dla zimowych gości lodowiska. Nie jest jasne, czy rotunda na Dynasach służyła, podobnie jak gmach 'Panoramy' przy ulicy Karowej, za wrotowisko czyli skate-rink [Tuszyński 1986]. Na początku XX w. rotunda służyła także jako siedziba teatrów letnich (m.in. Yiddish Theater Idy Kamińskiej), a w okresie międzywojennym - jako warsztaty samochodowe firmy Chevrolet (przerobiono XIX-wieczną rotundę na budynek w stylu modernizmu wg projektu Juliusza Żakowskiego i Zasława Malickiego). O wytworności i elitarności klubu sportowego Dynasy świadczy fakt, że jednymi z udziałowców 'Spółki Dynasy' był 
hrabia Leopold Kronenberg i hrabia August Potocki [Tuszyński 1986]. Klub WTC na Dynasach w Warszawie istniał do wybuchu II wojny światowej. Poza słynnym torem na Dynasach w elitarnym klubie WTC, w Warszawie na przełomie XIX i XX w. otwarto kilka małych 'cyklodromów', gdzie można było na ogrodzonym placu ćwiczyć ewolucje na własnym lub pożyczonym rowerze: przy ulicy Dobrej, Świętokrzyskiej, Leszno, Składowej, przy Alejach Jerozolimskich (na Powiślu) i przy ulicy Marszałkowskiej (blisko terenów ówczesnych Wyścigów na Polu Mokotowskim). Bez wątpienia, Józef Huss projektując tor kolarski na Dynasach w Warszawie znał inne ówczesne europejskie obiekty sportowe o takim przeznaczeniu. Welodromy powstawały w Europie już w połowie XIX w. Niewiele z tych konstrukcji miało na celu zawody wyłącznie cyklistów, najczęściej powstawały jako część boiska piłkarskiego lub do lekkiej atletyki, z wytrasowanym torem po jego obwodzie. Zanim zaczęły powstawać w kształcie owalnym, (co narzucają reguły zawodów międzynarodowych), budowano tory różnych kształtów, także proste lub na okręgu. Nawierzchnia najstarszych welodromów była z tłuczonej cegły lub żużlu zmieszanego z popiołem, później stosowano nawierzchnie $\mathrm{z}$ betonu lub asfaltu.

\section{Modernizm II RP}

Zniszczenia po I wojnie światowej zaważyły znacząco na ekonomii i gospodarce, strukturach społecznych, urbanistyce miast, także znacząco wpływając na kulturę, sport, architekturę i budownictwo. Po pierwszej i po drugiej wojnie światowej nastąpiła masowa odbudowa zniszczonych miast i miasteczek - domów mieszkalnych, infrastruktury miejskiej, szpitali i szkół, instytucji kultury oraz innych gmachów użyteczności publicznej - w tym obiektów sportowych. Pośpiech, dążenie do efektywnego procesu realizacji i jego potanieniu, sprzyjały koncepcji modernizmu, uproszczeniu form architektonicznych, rezygnacji z pracochłonnego detalu i ozdób elewacji typowych dla dotychczasowych stylów w architekturze. Była to prawdziwa rewolucja. W XX w., dzięki wprowadzeniu nowych technologii budowania i nowych materiałów (strunobeton, żelbeton, stalowe ramy konstrukcyjne, ściany kurtynowe, masy plastyczne, hartowane szkło i klejone płyty szklane), można było wznosić śmiałe budowle, o skali dotychczas nie znanej, mających doskonałe naturalne oświetlenie. Architektura ubiegłego wieku jest nazywana 'architekturą żeliwa, szkła i stali'. Zastosowanie tych innowacyjnych metod miało ogromne znaczenie dla obiektów sportowych, przede wszystkim wielkokubaturowych hal sportowych i stadionów. Ponieważ, jak to określa Lipoński [Lipoński 2012], w zakresie sportu XIX w. 'wiek uczestnika' został zastąpiony w XX w. 'wiekiem widza i spektaklu', monumentalne obiekty sportowe miały objętość odpowiednią do pomieszczenia wielotysięcznych tłumów kibiców. Różnice w ich wielkości w gruncie rzeczy zależą od pojemnością trybun i liczby funkcji jakie mieszczą - samo pole gry (dla danej dyscypliny) jest bowiem, poza nieznacznymi korektami, niezmienne. Na początku XX w. warszawskie elektrownie miejskie pozwalały bezpiecznie oświetlić sale gimnastyczne i otwarte tereny sportu, takie jak boiska dając możliwość dłuższego czasu użytkowania, szczególnie 
zimą i jesienią. Procesom uprzemysłowienia, zapoczątkowanym w XIX w., towarzyszyła gwałtowna urbanizacja Warszawy i innych miast, wywołana migracją ze wsi w poszukiwaniu zarówno pracy, jak i zwabioną miejskim stylem życia. Wyższy standard życia, ciekawsze rozrywki czasu wolnego to były także oczekiwania wobec miejskiej infrastruktury sportowej oraz rekreacyjnej. W miastach budowano sale gimnastyczne i pływalnie, korty tenisowe, boiska do gier drużynowych i stadiony, zakładano parki i zieleńce. Tym bardziej było to ważne, że - jak pisze Lipoński [Lipoński 2012], odrodzenie społeczne po spustoszeniach moralnych i fizycznych w wyniku I wojny światowej, było widziane przez sport i wychowanie fizyczne. Autor przewodnika po Warszawie, największego miasta ówczesnej guberni 'kraju przywiślańskiego', wydanego w 1912 r., wymienia kilkanaście ówczesnych klubów sportowych: Towarzystwo Wyścigów Konnych w Królestwie Polskim (Krakowskie Przedmieście 32), Klub Myśliwski (Erywańska 7), Warszawskie Koło Sportowe (Królewska 10), Towarzystwo Automobilistów Królestwa Polskiego (Hotel Europejski), Warszawskie Towarzystwo Cyklistów, Dynasy (Oboźna 1/3), Warszawskie Towarzystwo Łyżwiarskie, Dolina Szwajcarska (Szopena 5), Towarzystwo Zwolenników Gry Szachowej (Graniczna 8), Drugie Wojskowe Towarzystwo Myśliwskie (Nowolipie 2), Towarzystwo Lotnicze Awiata (Pole Mokotowskie). Ten sam przewodnik z 1912 r. zachwalał możliwość korzystania z torów ‘sportu na kółkach’ (wrotnisk, wrotowisk czyli skate-rink) w Dolinie Szwajcarskiej (przy Alejach Ujazdowskich), Galerii Luksemburga (przy ulicy Senatorskiej), w gmachu Panoramy (rotundy) przy ulicy Karowej oraz w Alejach Jerozolimskich 57. Być może organizowano także 'wrotnisko' w gmachu rotundy na Dynasach, na terenie klubu WTC [Zięcikowski1912], nie jest to jednak fakt potwierdzony w innych źródłach.

Należy podkreślić, że korzystanie z wymienionych obiektów sportowych było odpłatne i to niemało (w skate-rink koszt biletu wynosił w 1912 r. aż pół rubla za wejście i drugie pół za wypożyczenie 'łyżew kółkowych' czyli wrotek). Jeden z autorów wspomnień o dzieciństwie spędzonym w Warszawie [Tarasewicz 2005] podaje wysokie koszty i trudności z wyrobieniem karty wstępu do parku Agrykola (również wówczas nazywanym 'Parkiem Sobieskiego') przy ulicy Myśliwieckiej, co upoważniało ucznia gimnazjum do korzystania z Międzyszkolnego Ośrodka Sportowego (boiska piłkarskiego, bieżni i betonowych kortów tenisowych - zalążka Warszawskiego Lawn Tennis Klub). U podnóża Zamku Ujazdowskiego rozgrywano także od 1900 r. konkursy hippiczne (zbudowano tam tory i stajnie dla 250 koni). Wkrótce, bo po zakończeniu I wojny światowej, powstał w sąsiedztwie Agrykoli zespół obiektów sportowych Wojskowego Klubu Sportowego 'Legii', o bardzo bogatym programie. Wymienionym aktywnościom towarzyszyła budowa sal gimnastycznych i boisk sportowych, jednak dopiero po zakończeniu I wojny światowej i uzyskaniu niepodległości liczba klubów sportowych i budowli sportowych wzrosła w Polsce lawinowo.

O tym jak I wojna światowa tworzyła istotną cezurę w budownictwie sportowym, niechaj świadczy porównanie dwóch kompleksów domów akademickich: w Krakowie z 1903 r. i w Warszawie z 1930 r. W krakowskim Domu Akademickim (projekt Józef Pokutyński), przewidziano czytelnię i salę bilardowa, ale jest brak sali gimnastycznej, boiska i pływalni. Natomiast w warszawskim Domu Akademickim przy placu Narutowicza (projektu Kazimierza 
Tołłoczko) przewidziano już bogaty program sportowy, w tym krytą pływalnię wtopioną w bryłę obiektu, umiejscowioną na drugiej kondygnacji. Dzięki bezpośredniemu zaangażowaniu i wsparciu wojska budowa infrastruktury sportowej (np. zespołu CIWF na Bielanach w Warszawie) w imię upowszechniania tężyzny fizycznej wśród młodzieży przebiegała sprawniej. Powołano Biuro Projektów i Badań Technicznych, którego jednym z zadań było opracowanie projektów modelowych budowli sportowych [Nowakowski 1933].

Dynamizm budowy obiektów sportowych w okresie II RP dobrze ilustruje ruch inwestycyjny w Warszawie: w ciągu niespełna 10 lat wybudowano stadiony, pływalnie, hale sportowe, przystanie wodniackie i pływalnie (w tym kilka krytych), powstał zespół CIWF na Bielanach. Przed wybuchem II wojny światowej działało w mieście ogółem 130 klubów sportowych. Zainteresowanie władz rozwojem sportu, budowa nowoczesnych obiektów i lepsze warunki treningowe wpływały korzystnie na osiągnięcia i wyniki warszawskich sportowców, m.in. zdobywane na kolejnych igrzyskach olimpijskich. Tylko na warszawskim Żoliborzu, dzielnicy dopiero powstającej, działało wówczas kilka klubów sportowych, były to: Wojskowy Klub Sportowy 'Żoliborz', Robotniczy Klub Sportowy 'Marymont' (założony w 1911 r.), Towarzystwo Sportowe 'Promien' (założone w 1933 r.) oraz Koło Turystyczne Warszawskiej Spółdzielni Mieszkaniowej WSM. W planach na lata 40. była realizacja ambitnego i bogatego funkcjonalnie projektu Parku Sportów Wodnych, mającego powstać w rejonie dzisiejszego parku rekreacyjno-sportowego Kępa Potocka. Takie plany powstawały także dla innych dzielnic miasta (np. zespół sportowy w Rembertowie, z otwartą pływalnią projektu Romualda Gutta i Aleksandra Szniolisa).

Ustawa o zakładaniu i utrzymywaniu publicznych szkół powszechnych (Dz.U. Nr 18 z 1922 r.) nakładała obowiązek zapewnienia większym szkołom ponadpodstawowym sal gimnastycznych i sportowych boisk. Zalecano rezerwę terenu pod boisko do gier ruchowych i ćwiczeń o powierzchni łącznej około $2000 \mathrm{~m}^{2}$, przy minimalnej szerokości co najmniej $36 \mathrm{~m}$. Salę gimnastyczną zalecano budować o wymiarach $20 \mathrm{~m} \times 10 \mathrm{~m}$ ×5,5 m, w jej sąsiedztwie zapewnić szatnie, toalety i natryski. Wyposażenie sali gimnastycznej było szczegółowo regulowane przez rozporządzenie MWRiOP z 1936 r., zgodnie z katalogiem Ministerstwa musiały tam się znaleźć skrzynie, kozły, konie, drabinki, równoważnie, ławeczki. Co ciekawe, wspomniane przepisy nie wspominały o tablicach do gry w koszykówkę i mocowaniu siatki do gry w siatkówkę - najwyraźniej nie były to wówczas gry popularne. Budowane przed wybuchem II wojny światowej warszawskie szkoły miały boiska, sale gimnastyczne, szatnie i węzły sanitarne z prysznicami (np. Liceum Batorego projektu Tadeusza Tołwińskiego, Miejskie Gimnazjum Żeńskie przy ulicy Rozbrat projektu Tadeusza Majewskiego, szkoły przy ulicy Stawki i Żelaznej projektu Tadeusza Ćwierdzińskiego i Romana Sołtyńskiego, szkoła przy ulicy Krajewskiego projektu Romualda Gutta i Józefa Jankowskiego, szkoła przy ulicy Kolektorskiej projektu Wilhelma Henneberga, szkoła przy ulicy Zuga projektu Jerzego Przymanowskiego, szkoła przy ulicy Raszyńskiej projektu Mieczysława Łokciowskiego i Marii Wroczyńskiej, gimnazjum Słowackiego projektu T. Nowakowskiego, Państwowe Gimnazjum i Liceum im. ks. Józefa Poniatowskiego przy ulicy Felińskiego) (ryc. 6). 


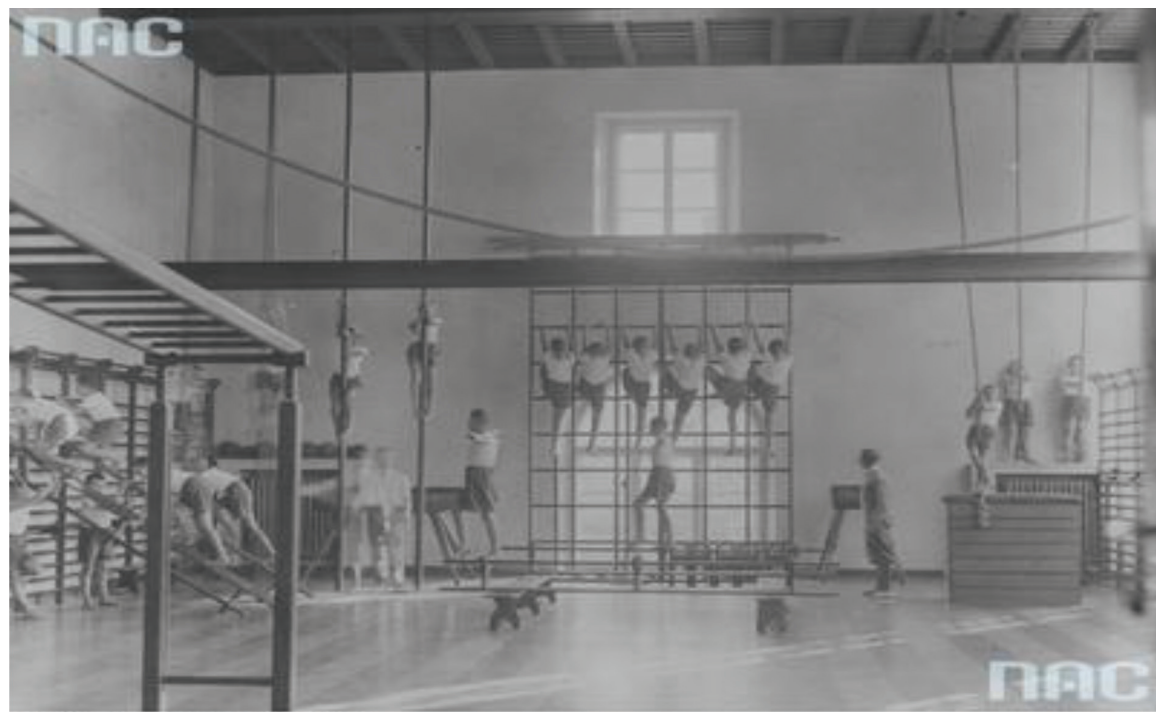

Ryc. 6. Szkolna sala gimnastyczna

Lekcja gimnastyki w Liceum im. Stefana Batorego w Warszawie, ok. 1924

Źródło: Fot. (autor nieznany, 1924), Narodowe Archiwum Cyfrowe [Domena Publiczna]

Szczególnie interesującym obiektem sportowo-dydaktycznym z tamtego okresu jest kampus CIWF na warszawskich Bielanach projektu Edgara Norwertha ${ }^{2}$. Projekt uczelni w Warszawie powstał z inicjatywy Marszałka Józefa Piłsudskiego, jako Centralny Instytut Wychowania Fizycznego. Uroczysta inauguracja pierwszego roku akademickiego odbyła się 29 listopada 1929 r. W 1938 r. CIWF imienia Pierwszego Marszałka Polski Józefa Piłsudskiego został przekształcony w Wojskową Szkołę Akademicką pod nazwą Akademia Wychowania Fizycznego Józefa Piłsudskiego w Warszawie. Projekt zespołu sportowo-dydaktycznego na warszawskich Bielanach zlecono Edgarowi Norwerthowi, który prace rozpoczął od ro-

\footnotetext{
${ }^{2}$ Edgar Aleksander Norwerth (1884-1950), był wybitnym polskim architektem, urbanistą i teoretykiem architektury, jednym z twórców modernizmu w architekturze polskiej. Studiował w Rosji, od $1924 \mathrm{r}$. mieszkał w Warszawie. W latach 1926-1930 prowadził wykłady na Wydziale Inżynierii Lądowej Politechniki Warszawskiej. Pracował na Politechnice Warszawskiej, prowadził pracownię projektowa, zajmował się grafiką (akwaforty i drzeworyty). Jego celne artykuły na temat teorii architektury były zamieszczane w czasopiśmie 'Architektura i Budownictwo'. Do jego najbardziej znanych prac należą: dworzec kolejowy Będzin Miasto (1931), kompleks Centralnego Instytutu Wychowania Fizycznego (obecnie Akademia Wychowania Fizycznego im. Józefa Piłsudskiego) na warszawskich Bielanach (1928-1930), pawilon GISZ wraz z kamienicą Wojskowej Spółdzielni Mieszkaniowej ‘Proporzec' ('Dom Pułkowników', 'Dom Generalski') przy al. Szucha w Warszawie (1931), osiedle mieszkaniowe Funduszu Kwaterunku Wojskowego w rejonie Cytadeli Warszawskiej, Żoliborz Oficerski (w latach 1932-1937), Dom Wychowania Fizycznego i Przysposobienia Obronnego w Kielcach (1933), dom własny przy ulicy Klonowej w Warszawie (1939), odbudowa i przebudowa kościoła św. Stanisława Kostki na warszawskim Żoliborzu (1945-1963), odbudowa Miejskiego Gimnazjum i Liceum Handlowego przy ulicy Krypskiej w Warszawie (1948), odbudowa Towarzystwa Naukowego Warszawskiego przy ulicy Śniadeckich (1948). Edgar Norwerth jest pochowany na Cmentarzu Powązkowskim w Warszawie.
} 
zeznania programów funkcjonalnych i rozwiązań architektonicznych innych placówek tego typu w Europie. Było ich wówczas tylko kilka o programie na poziomie uniwersyteckim, nie licząc kilkunastu małych prywatnych szkół sportu, na których nie było sensu, zdaniem Norwertha, się wzorować. W rezultacie inspiracją dla kampusu CIWF na Bielanach nie stał się ani Instytut Wychowania w Sztokholmie (założony w połowie XIX w., o przestarzałych już wobec nowych wymagań rozwiązaniach i konstrukcji), ani budowana w tym samym czasie Szkoła Sportu Ferenzina pod Rzymem (zdaniem Norwertha pompatyczna i niefunkcjonalna). Natomiast Hochschule für Leibesübungen pod Berlinem została przez Norwertha uznana za najbardziej zbliżoną programowo do tego, co chciano osiągnąć w Warszawie. Projekt CIWF był także wzorowany na założeniach dla uczelni sportowej przygotowanych przez Eugeniusza Piaseckiego z Poznania. Bez wątpienia jednak najbardziej istotną inspiracją dla Norwertha, pod kątem kompozycji urbanistycznej i wyboru stylu architektury, była wspomniana Wyższa Szkoła Wychowania Fizycznego w Gruenewaldzie pod Berlinem (Hochschule für Leibesübungen). Opierając się na doświadczeniach uczelni niemieckiej, polskim programie dydaktycznym oraz warunkach terenowych i oczekiwaniach inwestora, Edgar Norwerth przygotował plany dla kampusu na 80 ha, położonego na malowniczej Skarpie Wisły, w sąsiedztwie Lasu Bielańskiego. Założenie zespołu dydaktyczno-sportowego było oparte na zasadzie dwóch krzyżujących się na centralnym placu CIWF osi: wschód-zachód (prostopadłej do Wisły, na przedłużeniu reprezentacyjnej alei Zjednoczenia) oraz północpołudnie (równoległej do Wisły i ulicy Marymonckiej). Osią wschód-zachód planowanego na Bielanach założenia było przedłużenie alei Zjednoczenia, która na kampusie rozpoczynałaby się bramą (przy ulicy Marymonckiej), a kończyłaby się w części wschodniej monumentalnym Stadionem Narodowym, ulokowanym już na granicy Skarpy Wiślanej (ryc. 7).

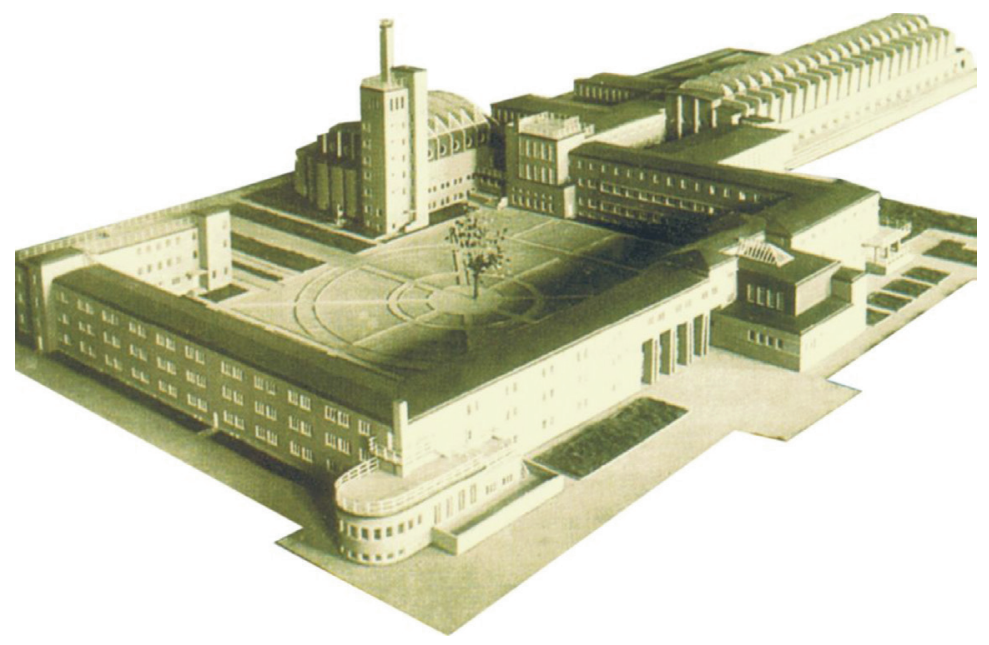

Ryc. 7. Centralny Instytut Wychowania Fizycznego Józefa Piłsudskiego w Warszawie (obecnie AWF Warszawa), proj. Edgar Norwerth, 1928

Źródło: Archiwum AWF Warszawa 
Osią poprzeczną na linii północ-południe miał być budynek główny z krytą pływalnią (konstrukcja dachu wspierana przez ramy żelbetowe o rozpiętości $24 \mathrm{~m}$ ), salami wykładowymi (w tym aula na 250 miejsc), monumentalną halą ćwiczeń (o rzadko wówczas spotykanych rozmiarach: $130 \mathrm{~m}$ x 22 m, konstrukcji z 24 ram żelbetowych). Równolegle do budynków na osi północ-południe, w części północnej kompleksu, zaplanowano ciąg boisk sportowych (do piłki nożnej i rugby, ćwiczeń lekkoatletycznych, gimnastyki), z lodowiskiem, salami do treningu, zapasów i judo, kortami tenisowymi i odkrytą pływalnią. Akademik męski (wraz $\mathrm{z}$ ambulatorium z osobnym wejściem) były zaplanowane w części południowej założenia, wzdłuż osi północ-południe, jako przedłużenie korpusu budynku głównego, natomiast dom akademicki żeński w części północnej, oderwany od korpusu budynku głównego. Domy mieszkalne dla wykładowców zaplanowano równolegle do budynków na osi południowej założenia. Dominantą nad zespołem obiektów miała być wysoka na 36 metrów wieża ciśnień przy pływalni (posadowiona na osobnej płycie zbrojeniowej), ukrywająca w swoim korpusie 'nieestetyczny, ale niezbędny' (wg słów samego Norwertha) komin. Projektantom założenia - Norwerth zaprosił do współpracy studentów z Wydziału Architektury Politechniki Warszawskiej - bardzo zależało na zachowaniu bujnej zieleni Lasu Bielańskiego. Stąd m.in. pomysł ‘Propylejów', monumentalnych filarów, przez które widać drzewa, niestety nie udało się to $\mathrm{w}$ takim stopniu, $\mathrm{w}$ jakim o to zabiegali. E. Norwerth bardzo niepokoił się losem samotnej czarnej wierzby rosnącej w centrum założenia, ponieważ nie tylko cenił jej urodę, ale także uważał, że stanowi ważny akcent kompozycyjny dziedzińca głównego (obecnie drzewo jest otoczone prawna, indywidualną ochroną konserwatorska, jako cenny Pomnik Przyrody). Autorami projektów wnętrz uczelni (także projektów mebli wykonywanych na indywidualne zamówienie), dla kasyna, jadalni, sal internatów studenckich - byli zaproszeni do współpracy studenci z Politechniki, którzy starali się, pomimo skromnych środków na realizację, osiągnąć wygodę i elegancję. Styl, w jakim zaprojektowano CIWF, historycy określają jako 'modernizm monumentalny', możemy w nim jednak także znaleźć ślady ekspresjonizmu, szczególnie inspirację projektami niemieckiego architekta Ericha Mendelsohna (na przykład charakterystyczne podkreślenia otworów okiennych). E. Norwerth planował na elewacjach budynków tynki szlachetne, jednak ani wówczas, ani obecnie nie jest to możliwe ze względu na brak środków. Nieco gorzko autor pisał o tych narzucanych mu przez inwestora budowy ograniczeniach na łamach 'Architektury i Budownictwa': „Przy systemie skrajnej oszczędności, dążącej do możliwie jak najszerszego wykonania programu (...), nie mogło być mowy o jakimkolwiek podniesieniu się ponad poziom ścisłej użyteczności. Jedynym luksusem dekoracyjnym jaki w naszem rozporządzeniu pozostał - było piękne i bogate zadrzewienie terenu, to też nie żałowano wysiłków, do jak najszerszego wykorzystania go, z wyjątkową pieczołowitością starając się uwydatnić każdy nadający się moment dekoracyjny. Nie wszystkie się udały. Jedne przedwcześnie zginęły śmiercią naturalną, inne padły ofiarą żelaznej użyteczności. Pozostała, niewiadomo na jak długo, rozłożysta topola w środku podwórza, wspaniale ożywiająca skromny zarys murów." [Norwerth 1930a, s. 426]. Pomimo koniecznych stałych oszczędności, o których autor projektu wspomina, pomimo niezrealizowania wszystkich elementów planowanego założenia (reprezentacyjnego stadionu, 
odkrytej pływalni, hali dla hokeja na lodzie, amfiteatru czy torów wioślarskich na Wiśle) bez wątpienia zespół CIWF należy śmiało uznać za wybitne dzieło kompozycji urbanistycznej, przykład niezrównanej harmonii i elegancji, funkcjonalnej i ponadczasowej kompozycji kampusu uczelni sportowej. Zespół obiektów uczelni, do dzisiaj dobrze służy kolejnym pokoleniom studentów i wykładowców - pod zmienioną nazwą Akademii Wychowania Fizycznego Józefa Piłsudskiego w Warszawie [Pawlikowska-Piechotka 2019].

Z poparciem Marszałka Józefa Piłsudskiego, wzniesiono przed wybuchem II wojny światowej w Warszawie, zespół obiektów sportowych Legii, do dzisiaj istniejący przy ulicy Łazienkowskiej. Do czasu budowy stadionu Legii, Warszawa nie tylko nie miała żadnego stadionu, ale jedynym treningowym boiskiem piłkarskim było stare, XIX-wieczne boisko na Agrykoli. Na przełomie 1921/1922 rozpoczęto prace nad budową stadionu, pływalni i zespołu kortów na gruntach państwowych liczących 16 ha, w rejonie ulic Czerniakowskiej, Łazienkowskiej i Myśliwieckiej. Wojskowy Klub Sportowy Legia doczekał się stadionu w sierpniu 1930 r., kiedy dokonano jego oficjalnego otwarcia. Projekt przewidywał wybudowanie pełnowymiarowego boiska piłkarskiego wraz z trybunami, otoczonego sześciotorową bieżnią żużlowa, dwóch boisk treningowych i kompleksu kortów tenisowych. Autorem planów byli inżynierowie: Maksymilian Dudryk-Darlewski, Aleksander Kodelski, Julian Nagórski (autor m.in. stadionu 'Polonii' w Warszawie). Rozszerzono projekt pierwotny o budowę basenu pływackiego, krytej trybuny na 6000 miejsc, 500-metrowej bieżni o szerokości 8 metrów, lokali klubowych i zaplecza (szatnie, magazyny, ambulatorium, bufet, pomieszczenia administracji, hotel), projektu Aleksandra Kodelskiego (ryc. 8-11).

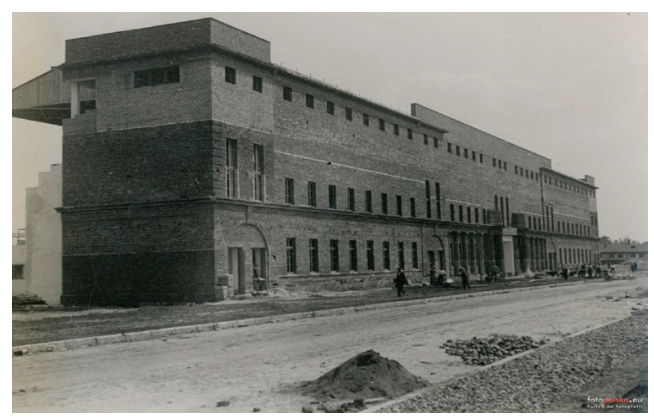

Ryc. 8. Stadion Legii w Warszawie Widok trybun od ulicy Myśliwieckiej, obiekt w trakcie budowy, ok. 1929

Źródło: Fot. (autor nieznany, 1929), Archiwum KS Legia Warszawa

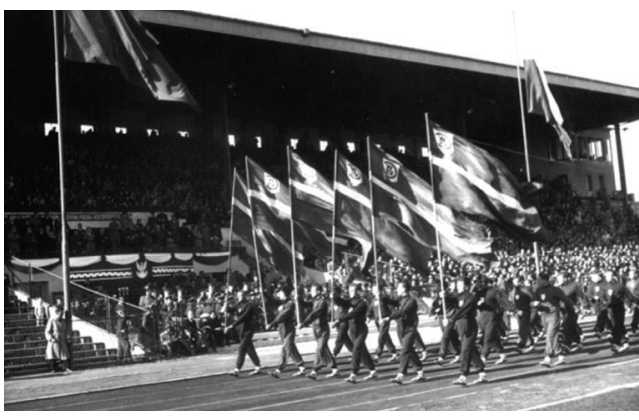

Ryc. 9. Stadion Legii w Warszawie Uroczyste otwarcie Stadionu Wojska Polskiego, 1930

Źródło: Fot. (autor nieznany, 1930), Archiwum KS Legia Warszawa 


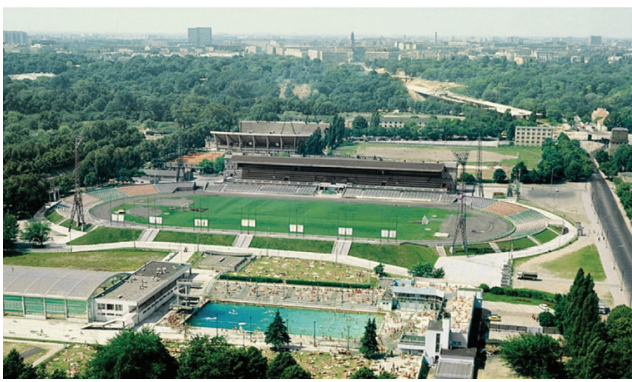

Ryc. 10. Zespół KS Legii Warszawa po odbudowie ze zniszczeń wojennych i modernizacji, ok. 1970 Na pierwszym planie pływalnia kryta i otwarta z wieżą do skoków

Źródło: Fot. (autor nieznany, 1970), Archiwum KS Legia Warszawa

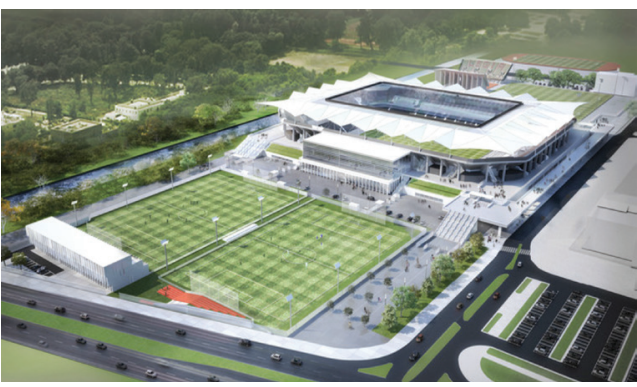

Ryc. 11. Zespół KS Legia Warszawa Plany modernizacji i rozbudowy stadionu i zespołu boisk, ok. 2010

Źródło: Fot. (autor nieznany, 2010), Archiwum KS Legia

Reprezentacyjny stadion 'Legii' wykorzystywano nie tylko do organizacji wydarzeń sportowych, miały tam miejsce także liczne uroczystości państwowe (np. defilady z okazji rocznic). Na terenie WKS Legia planowano też budowę krytego lodowiska i hali sportowej, modernizację toru kolarskiego i budowę toru do jazdy szybkiej na lodzie. Środki na budowę zdobywano z rożnych źródeł, miedzy innymi YMCA. Wcześniej niż stadion, bo w 1928 r. został w zespole 'Legii' otwarty basen północny wraz z 10-metrową skocznią (projekt inżynierów Aleksandra Kodelskiego i Romualda Raksimowicza). Szatnie otaczały basen z dwóch stron - zaplanowane w kształcie litery L, a trybuny mogły pomieścić 2500 osób. Inwestorem tej części budowy był Polski Związek Pływacki. Pływalnia Klubu Sportowego 'Legia' (projekt Aleksander Kodelski) z charakterystyczną, rzeźbiarsko potraktowaną wieżą do skoków oraz modernistycznym, bardzo eleganckim wejściem od ulicy Myśliwieckiej - była uznana za jeden z najwybitniejszych przykładów architektury sportowej dwudziestolecia międzywojennego. W 1933 r., stadion oficjalnie zyskał miano Stadionu Wojska Polskiego. Latem tego samego roku, obiekt przeszedł w administrację Państwowego Urzędu Wychowania Fizycznego (ranga ówczesnego ministerstwa sportu). W styczniu 1933 r. na jednym z boisk tenisowych zorganizowano lodowisko, na którym mogły rozgrywać się mecze hokejowe. Plac gry otaczały trybuny, które mogły pomieścić 4000 widzów [Janiszewska 2012]. W okresie okupacji stadion służył do treningów i zawodów żołnierzy Wehrmachtu. Po II wojnie światowej, zniszczony w czasie działań wojennych stadion, boiska treningowe, korty i pływalnię odbudowano (autorami projektu odbudowy byli: Jerzy Hryniewiecki, Marek Leykam, Czesław Rajewski, Tadeusz Rupniewski, 1956-1968). W 1953 r. w sąsiedztwie terenów sportowych 'Legii' zostało otwarte drugie w kraju sztuczne lodowisko - 'Torwar', w 1956 r. Legia pozyskała długo oczekiwany kolejny obiekt sportowy, jakim była planowana już przed wybuchem II wojny światowej hala sportowa. W latach 60. zespół był poddany zabiegom modernizacyjnym, wybudowano kryty basen, stadion mógł pomieścić blisko 30000 osób [Drozdowski, Zahorski 1981]. W 2008 r. rozpoczęto rozbiórkę starego stadionu i starych 
budynków klubowych, aby uzyskać teren pod budowę nowego zespołu sportowego 'Legii'.

Nieporównaną, bo na znacznie mniejszą skalę, zamierzona była inwestycja obiektów sportowych dla Klubu 'Polonia' w Warszawie, ale jej historia dobrze obrazuje losy polskich obiektów sportowych w XX w. Na początku II RP zawodnicy KS ‘Polonii’, tak jak inne kluby piłkarskie Warszawy, nie mieli własnego boiska i trenowali na terenach sportowych Agrykoli. W 1923 r. klub otrzymał od miasta 5-hektarową działkę gruntu przy ulicy Konwiktorskiej, na terenach dawnej Cytadeli. Była to działka przeznaczona jeszcze w 1916 r. w urbanistycznych Planach Regulacyjnych Warszawy (autorstwa Tadeusza Tołwińskiego) na tereny sportu. Architekt Juliusz Nagórski (uznany twórca licznych obiektów sportowych, m.in. współautor stadionu 'Legii') zaplanował tam duży stadion z trybunami na 20000 miejsc. We wrześniu 1928 r. nastąpiło oficjalne otwarcie stadionu, na którym pułkownik Juliusz Ulrych wygłosił pamiętne słowa: „Klub nie może być odgrodzony chińskim murem od świata. Musi być jak czytelnia ludowa - otwarty i dostępny dla szerokiego ogółu”. Stadion 'Polonii' miał boisko piłkarskie, otaczającą je bieżnię lekkoatletyczna, cztery korty tenisowe, wielofunkcyjne boisko do gier sportowych, od strony Bonifraterskiej wybudowano trybuny na 10000 miejsc. Począwszy od zimy w 1930 r. boisko do gier zamieniano w lodowisko (ze sztucznym oświetleniem i radiowęzłem). Tor do jazdy szybkiej urządzano także na bieżni (od 1935), ale było to tylko wtedy możliwe, kiedy mroźne warunki zimowe na to pozwalały. W czasie okupacji stadion był przejęty przez niemiecką policję. Odbudowany po zniszczeniach wojennych stadion został oddany do użytku w 1950 r. Wybudowano też od strony Konwiktorskiej, w stylu socrealistycznym, ale bez zbędnego zadęcia i pompy, harmonijny i zgrabny, wielofunkcyjny budynek klubowy (mieszczący: pływalnię, salę treningową i szatnie). Był opisywany w ówczesnej prasie, zgodnie z propagandowym duchem epoki, jako 'pałac sportu dla ludu', zyskując to miano prawdopodobnie dzięki eleganckiej frontowej kolumnadzie w stylu jońskim (projekt wg niezrealizowanej koncepcji i szkiców Tadeusza Tołwińskiego - wykonał Julian Brzuchowski w 1954 r., rzeźba sportowca na froncie jest sygnowana: J. Komis). Obecnie wciąż są dla 'Polonii' przygotowywane plany modernizacji i rozbudowy zespołu (w tym powiększenia niecki basenu pływackiego i budowy hali sportowej), jednak poza zadaszeniem i remontem trybun oraz nowymi wejściami od strony Bonifraterskiej - są to wciąż tylko niezrealizowane plany, odkładane na bliżej nieokreśloną przyszłość [Janiszewska 2012].

Poza opisanymi stadionami, przed wybuchem II wojny światowej w Warszawie było kilkanaście boisk do gry w piłkę nożną: Fort Bema (planowana tam budowa wielkiego stadionu nie została nigdy zakończona), Skra (ulica Okopowa), Warszawskie Towarzystwo Cyklistów (Dynasy), Lilpopianka, Orkan, Syrena i Sokół (Wola), Warszawianka (Pola Mokotowskie - ulica Uniwersytecka), Skoda (Okęcie) oraz po stronie praskiej: Makabi, Dom Ludowy (ulica Zieleniecka), AZS (Park Skaryszewski), Orzeł przy Podskarbińskiej [Drozdowski, Zahorski 1981].

Popularność sportów wodnych sprawiła, że po odzyskani niepodległości, dzięki poparciu państwa oraz prywatnych donatorów, pojawiały się liczne kluby wodniackie. W samej Warszawie pojawiło się nad Wisłą w okresie II RP ponad dwadzieścia przystani sportowych, w tym kilka mających murowane obiekty klubowe. Były przeważnie lokalizowane po stronie lewobrzeżnej miasta, między mostami Kierbedzia i Poniatowskiego, gdzie przystąpiono do porządkowania nabrzeży i budowy wiślanych bulwarów (była to osobista inicjaty- 
wa ówczesnego prezydenta Warszawy - Stefana Starzyńskiego). Na warszawskim odcinku Wisły znajdowały się w okresie międzywojennym przystanie Warszawskiego Towarzystwa Wioślarskiego WTW, AZS, Wojskowego Klubu Wioślarskiego (otwarty w 1921 klub chlubił się eleganckim kąpieliskiem i sztuczną plażą na drewnianych pontonach), Klubu Wioślarskiego Wisła, Syreny, Domu Ludowego, Kuratorium Oświaty. Po stronie praskiej powstały przystanie klubu Makabi, Sokoła, YMCA, Yacht Klubu Polski, Policyjnego Klubu Sportowego PKS oraz siedziby i przystanie klubów wodniackich pocztowców, bankowców i kolejarzy [Janiszewska 2012]. W północnej części miasta znajdował się Wojskowy Klub Sportowy 'Żoliborz', po 1949 r. przemianowany na Klub Sportowy 'Spójnia'. Klub mieścił się w obiekcie przy Wybrzeżu Gdyńskim 2, mającym wiele sekcji sportowych - tenisa ziemnego, piłkarską, kajakowa, żeglarska, pływacka, wioślarską i motorowa, jednak z przewagą wodniackich. W 1933 r. rozpoczęło na Żoliborzu działalność Towarzystwo Sportowe 'Promien', z sekcją żeglarską i kajakowa, do której należał mieszkający w pobliżu Melchior Wańkowicz, staraniem Towarzystwa powstała przystań i plaża nad Wisłą. Wśród wielu warszawskich przystani wodniackich, przeważnie niewielkich i skromnych, wyróżniały się trzy murowane obiekty, niezwykle prestiżowe, okazałe i eleganckie. Szczególne zainteresowanie z uwagi na klasę architektury wzbudzał Oficerski Yacht Klub RP, projektu Juliusza Nagórskiego (1930) zlokalizowany w pobliżu Mostu Średnicowego. Budowę Oficerskiego Yacht Klubu rozpoczęto w 1931 r. Budynek był gotów w 1932 r. i ówczesna prasa warszawska z zachwytem pisała o modnej formie gmachu, eleganckiej modernistycznej architekturze. Okazały gmach Oficerskiego Yacht Klubu, już nie istnieje, ale został uwieczniony na fotografiach oraz w popularnym przedwojennym filmie ‘Jadzia' ${ }^{3}$. Należy podkreślić, że Oficerski Yacht Klub mieścił jeden z kliku krytych basenów w Warszawie, salę gimnastyczna, sale klubowe, restaurację. Niestety został zniszczony w czasie II wojny światowej i nigdy nieodbudowany (ryc. 12 i 13).

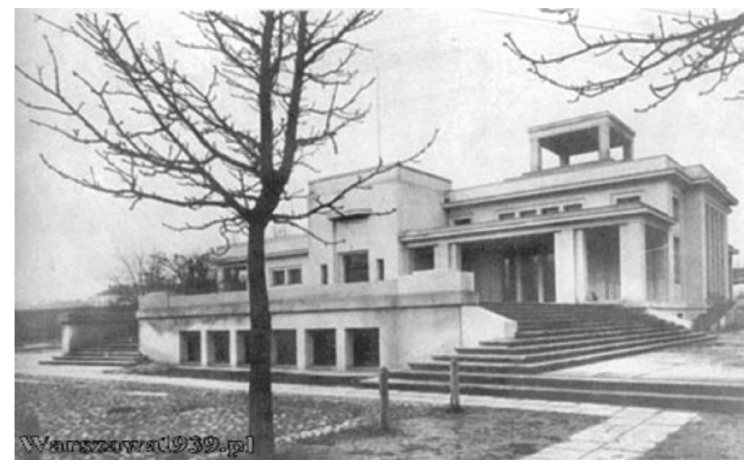

Ryc. 12. Stołeczny Oficerski Yacht-Klub R.P. w Warszawie, stan przed 1939, elewacja wschodnia (proj. Julian Nagórski). Obiekt nieodbudowany po zniszczeniach wojennych

Źródło: Fot. (autor nieznany, 1939), archiwum cyfrowe fotografii, fotopolska.eu. [Domena Publiczna]

\footnotetext{
${ }^{3}$ Film ‘Jadzia' z 1936 r., w reżyserii Mieczysława Krwawicza, z udziałem Jadwigi Smosarskiej.
} 


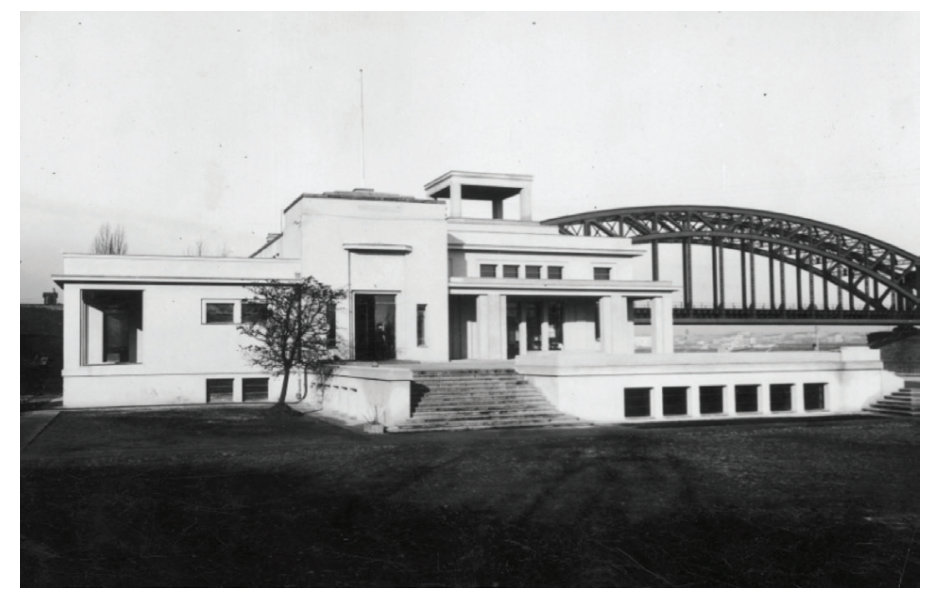

Ryc. 13. Stołeczny Oficerski Yacht-Klub R.P. w Warszawie nad Wisłą, stan przed 1939, elewacja południowa (proj. Julian Nagórski). Obiekt nieodbudowany po zniszczeniach wojennych Na drugim planie - zarys konstrukcji łukowej zniszczonego w czasie działań wojennych Mostu Kierbedzia

Źródło: Fot. (autor nieznany, 1939), archiwum cyfrowe fotografii, fotopolska.eu. [Domena Publiczna]

W 1929 r. otwarto nową przystań Warszawskiego Towarzystwa Wioślarskiego WTW, przy ul. Wioślarskiej, uznaną za najnowocześniejszy wówczas obiekt sportowy tego typu w Europie. Był to okazały murowany budynek o trzech kondygnacjach. Na kondygnacji przyziemia znajdował się basen wioślarski do treningów zimowych oraz hangary na łodzie. Wysoki parter zajmowały szatnie dla 800 osób z natryskami i umywalniami oraz taras widokowy od strony Wisły. Na piętrze klubu WTW urządzono dużą salę restauracyjną z tarasem pod arkadami ciągnącymi się przez całą szerokość elewacji oraz pokoje klubowe i administracyjne. W oddzielnym budynku były warsztaty szkutnicze oraz mieszkania służbowe pracowników. Nowy budynek przystani WTW (projektu Jerzego Mikulskiego) był wówczas jedną z największych przystani wioślarskich w Europie [Janiszewska 2012]. Historyczna, drewnianą przystań pływającą wyciągnięto na brzeg Wisły, ustawiono od strony południowej nowego budynku klubowego. Budynek był wykorzystywany jako czytelnia i salon gier towarzyskich, a z wysokiej wieżyczki na jej szczycie korzystali sędziowie podczas regat. O starym, jeszcze drewnianym budynku Klubu WTW, wspominał z uznaniem, jako wyróżniającym się estetyką i elegancją na tle innych - autor Najnowszego Ilustrowanego Przewodnika po Warszawie i Okolicach z 1912 r. [Zięcikowski 1912] takimi słowami: „Niejaką ozdobę brzegów wiślanych tworzy Przystań Tow. Wioślarskiego z prawej strony Wisły, gdzie latem panuje nawet duże ożywienie". Pochwały te wygłasza w odróżnieniu od krytyki innych przystani, które opisuje w ten sposób: „Przytem do zeszpecenia brzegów przyczyniają się bardzo brzydkie, brudne, sklecone byle jak, stacje wodne." Naturalnie ten komentarz odnosi się do okresu sprzed I wojny światowej. 
Trzecią murowaną przystanią nad Wisłą był piętrowy, niewielki i skromny, ale bardzo zgrabny budynek Klubu Syrena, wyróżniający się elegancką kolumnadą frontowej elewacji oraz monumentalnymi, reprezentacyjnymi schodami zewnętrznymi (stał przy nich pomnik warszawskiej Syrenki, obecnie stojący na Rynku Staromiejskim). Niestety wszystkie opisywane obiekty zostały zniszczone w czasie II wojny światowej i nigdy nie zostały odbudowane (ryc. 14).

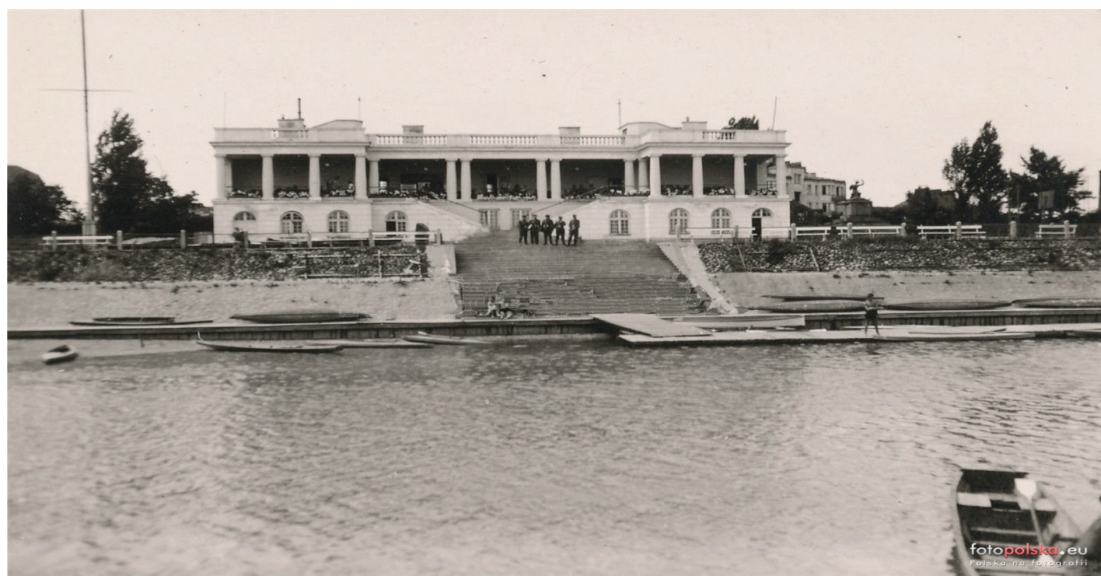

Ryc. 14. Klub Wioślarski Syrena w Warszawie, stan przed 1939, elewacja wschodnia Obiekt nieodbudowany po zniszczeniach wojennych

Źródło: Fot. (autor nieznany, 1939), archiwum cyfrowe fotografii fotopolska.eu. [Domena Publiczna]

Interesującą formę architektoniczną miał także budynek Przystani Wioślarskiej należący do Policyjnego Klubu Sportowego (projektu Eugeniusza i Zygmunta Piotrowskich). Był niewielkim, zgrabnym budynkiem o jasnym podziale funkcji: parter przeznaczony na warsztaty szkutnicze i służący jako hangar na łodzie, piętro natomiast miało funkcje klubowe, $\mathrm{z}$ restauracją i przestronnym tarasem.

W północnej dzielnicy na Żoliborzu powstał Wojskowy Klub Sportowy 'Żoliborz' nad Wisłą z przystanią wioślarska, hangarami i kortami tenisowymi, na miejscu dawnego Klubu Wojskowego 'Cytadela' i drewnianego budynku przystani. Po II wojnie światowej został przemianowany na Klub Sportowy ‘Spójnia' - przy ulicy Wybrzeże Gdyńskie 2 wybudowano murowany budynek klubu, rozebrany na początku XXI w. z powodu korekty trasowania linii drogowych Wisłostrady (ryc. 15). 


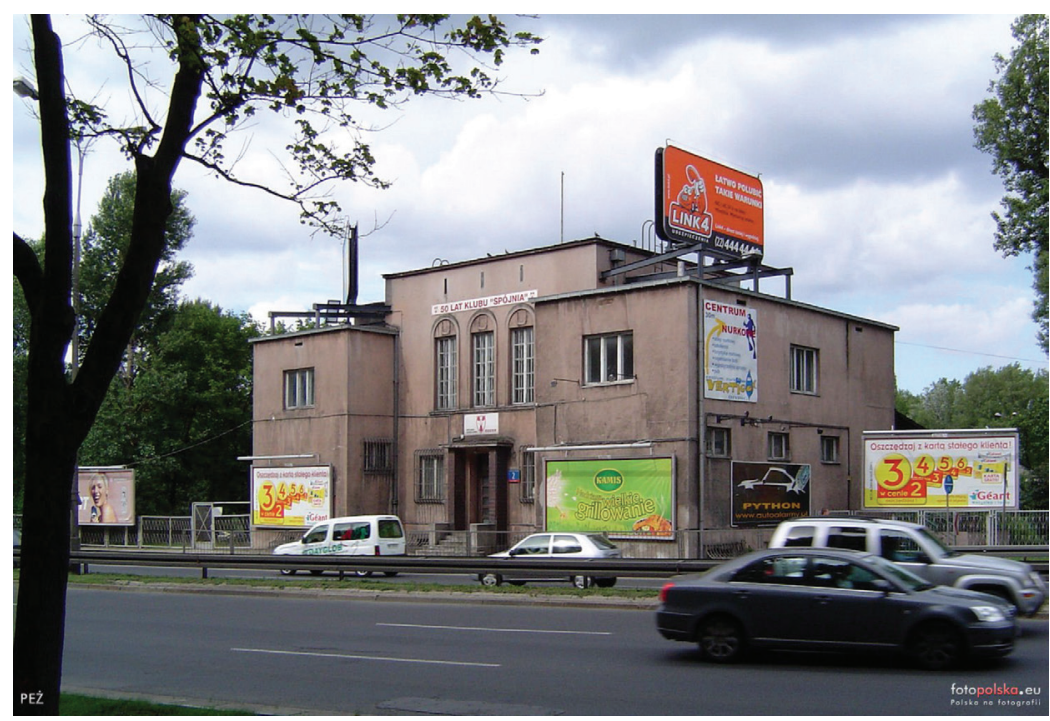

Ryc. 15. Budynek Klubu Sportowego 'Spójnia' przy ulicy Wybrzeże Gdyńskie 2 w Warszawie stan przed 2010, obiekt rozebrany z powodu korekty trasowania Wisłostrady

Źródło: Fot. PEŻ, Archiwum Cyfrowe fotopolska.eu

Tuż przed wybuchem II wojny światowej w Warszawie były 23 przystanie wodniackie (w tym opisane, murowane, okazałe budynki): Wojskowy Klub Sportowy WKS Żoliborz, Klub Sportowy Promień, Oficerski Yacht Klub (wcześniej Wojskowy Klub Wioślarski), Klub Dom Ludowy, Akademicki Związek Sportowy AZS, Warszawskie Towarzystwo Wioślarskie WTW, Klub Sportowy Wisła, Warszawski Klub Wodniacki Syrena, Klub Sportowy Varsovia, Klub Sportowy Związku Urzędników Kolei, Klub Rodzina Urzędnicza, Klub Zjednoczenie, Klub Makabi, Klub Sportowy Związku Urzędników Administracji Wojskowej ZUAW, Klub Sokół, Young Men Christian Association YMCA, Klub Sportowy Rodziny Wojskowej PPW, Klub Sportowy Skra, Klub Sportowy Strzelec, Yacht Klub Polski YKP, Klub Policyjny, Klub Sportowy PKS. Latem, przy prawie wszystkich klubach wodniackich, otwierano kąpieliska, organizowano naukę pływania, w tym zorganizowane kursy w 'basenach pływających', z brezentowym regulowanym dnem i przepływającą wodą wiślaną [Janiszewska 2012].

W planach urbanistycznych rozwijającej się dynamicznie w latach 30. na północy miasta dzielnicy Żoliborz, było powstanie Parku Sportów Wodnych nad Wisła, w sąsiedztwie planowanego Parku Moniuszki (teren dzisiejszego Parku Kępa Potocka i Rodzinnych Ogrodów Działkowych). W założeniach, obok przystani jachtowej i toru regatowego, miało powstać kąpielisko zespołu otwartych basenów (o łącznej powierzchni $5600 \mathrm{~m}^{2}$ i głębokości 1,5 m). Miały być zasilane wodą rzeczną, ale filtrowane (co było sanitarną koniecznością z powodu zanieczyszczeń rzeki, ponieważ w pobliżu, na przedłużeniu ulicy Krasińskiego było ujście kanału zrzucającego ścieki do Wisły). Zespół miał być uzupełniony stadionem z trybunami dla 5000 widzów, boiskami sportowymi, kortami tenisowymi. Jak słusznie przypomniał 
recenzent tej pracy, prof. Stanisław Piekarski, odcinek Wisły w Warszawie między Mostem Średnicowym a Mostem Poniatowskiego służył tradycyjnie, już od końca XIX w., jako tor wodny, na którym organizowano regaty wioślarskie, żeglarskie i sporty motorowodne. Na tym odcinku rzeki powstawała też większość klubów wodniackich, wyjątkiem były kluby budowane na Żoliborzu.

Na początku lat 30., przed wybuchem II wojny światowej, powstał w Warszawie słynny, opisany w Dzienniku 1954 Leopolda Tyrmanda - gmach Polska YMCA (inwestorem było stowarzyszenie Young Men Christian Association) przy ulicy Konopnickiej 6 w Warszawie, o innowacyjnej wówczas technologii z gazobetonu suporex. Był to dom mieszkalno-klubowy z rozbudowanym programem sportowym, m.in. z pływalnią i salami gimnastycznymi (projekt Antoni Jawornicki, 1931) (ryc. 16.). Poza gmachem YMCA warszawskie kryte baseny pływackie mieściły się w zespole CIWF na Bielanach, akademiku Politechniki przy placu Narutowicza (tzw. Kolonia Akademicka, projekt Kazimierz Tołłoczko), przy ulicy Wolskiej oraz w Oficerskim Yacht Klubie nad Wisłą.

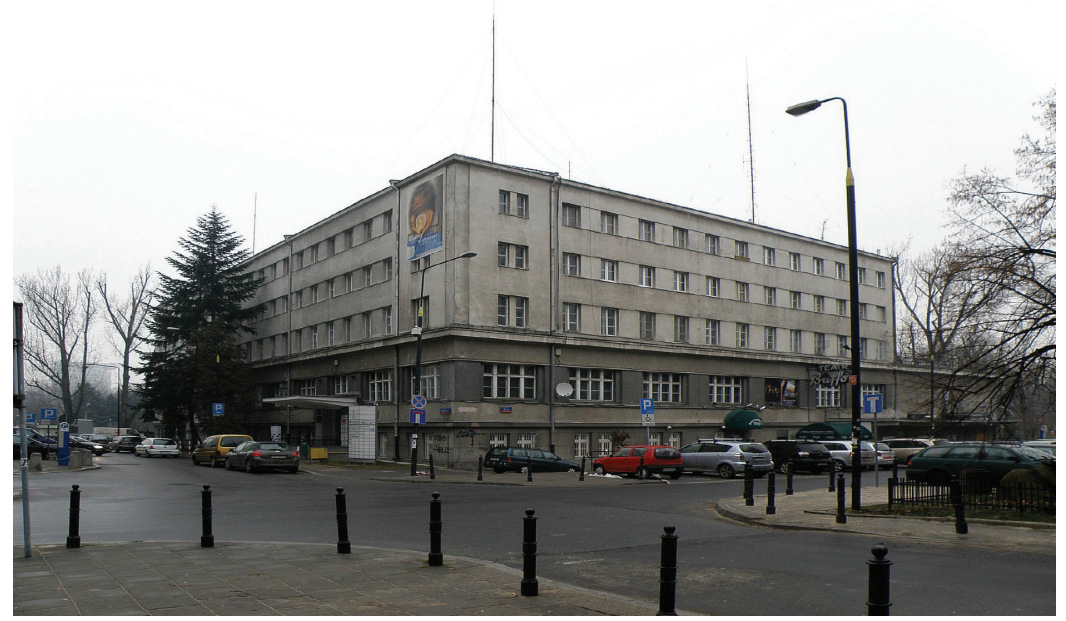

Ryc. 16. Gmach YMCA w Warszawie przy ulicy M. Konopnickiej, stan współczesny Wewnątrz znajdowały się liczne obiekty sportowe: sale ćwiczeń, kryta pływalnia (proj. Antoni Jawornicki, 1934)

Źródło: Fot. (autor nieznany, 2014), archiwum cyfrowe fotografii fotopolska.eu [Domena Publiczna]

Wcześniej opisaną jedyną w ówczesnej Warszawie otwartą pływalnię (poza sezonowymi kąpieliskami nad Wisłą) otworzono w 1928 r. przy ulicy Łazienkowskiej, jako część zespołu Wojskowego Klubu Sportowego ‘Legia’ [Janiszewska 2012].

Staraniem Towarzystwa Międzynarodowych i Krajowych Zawodów Konnych w 1927 r. wybudowano w Warszawie hipodrom w Łazienkach, z drewnianymi, piętrowymi trybunami dla widzów. Traktowano je jednak tylko jako obiekt tymczasowy, uzupełniający wciąż funkcjonujące tory wyścigów na Polu Mokotowskim (planowano już ich likwidację z powo- 
du budowy reprezentacyjnej dzielnicy rządowej i Świątyni Opatrzności). W tych okolicznościach zapadła decyzja budowy nowoczesnego obiektu hipodromu na Służewcu. Bez wątpienia oddane do użytku w 1939 r., nowe tory wyścigów konnych na Służewcu w Warszawie były niezwykle eleganckim i pięknym obiektem sportowym, jednym z najciekawszych przykładów architektury modernizmu II RP. Przed wybuchem II wojny światowej były uznane za najnowocześniejszy obiekt sportowy tego typu w Europie. Architektem, któremu powierzono projekt nowego kompleksu wyścigów był inżynier pochodzący z arystokratycznej rodziny - hr. Zygmunt Plater-Zyberk. Przygotował projekt warszawskiego Zespołu Wyścigów we współpracy z Juliuszem Żórawskim, Januszem Alchimowiczem, Tadeuszem Giżyckim, Janem Siwkiem, Olgierdem Tarnowskim, Jerzym Wasilewskim, Olgierdem Wojciechowskim oraz Jerzym Grabowskim. Inżynier Plater-Zyberk był już wówczas doświadczonym i uznanym projektantem, autorem wielu nowoczesnych domów mieszkalnych w Śródmieściu Warszawy (przy ulicy Chocimskiej, alei Niepodległości, alei Szucha). Bez wątpienia jednak to właśnie tory wyścigowe na Służewcu zapewniły mu miejsce wśród wybitnych architektów europejskich XX w. Z. Plater-Zyberk zanim przystąpił do projektu torów na Służewcu, odwiedził wszystkie najlepsze tory wyścigowe w Europie, dzięki którym poznał najnowsze rozwiązania techniczne, jak na przykład możliwość sztucznego zraszania murawy. Teren był trudny, tak opisywany we wspomnieniach projektanta: „Pod względem ogólnego ukształtowania teren nie był idealny, przecięty rzeczką i stawem na dwie części o znacznej różnicy poziomów" [Mórawski 2007]. Główny tor ma 2300 m (w osi północ-południe), jego kształt (łuki) i wytrasowanie zaprojektowano pod katem możliwości koni pełnej krwi angielskiej. Trzy trybuny mogły pomieścić razem około 12000 widzów, były zorientowane na wschód, aby uniknąć utrudniającego widoczność silnego popołudniowego nasłonecznienia. Trybuna I (tak zwana 'Członkowska') była przeznaczona dla VIP, jej goście mieli do dyspozycji saloniki i restaurację. W tym samym segmencie były pomieszczenia dla sędziów oraz trybuna przeznaczona dla personelu. Do tej trybuny był możliwy dojazd bezpośrednio samochodem, z osobnego wjazdu na teren Wyścigów. To ta trybuna jest architektoniczną ikoną i wyróżnikiem warszawskich torów, dzięki zaokrąglonej ścianie szczytowej i przeszklonej ścianie kurtynowej zaprojektowanej przez trzy kondygnacje od strony padoku. Trybuna II (główna) mogła pomieścić na miejscach siedzących 5400 osób. W jej podziemiach umieszczono sale dancingową z ruchomym parkietem. Na Trybunie III były miejsca stojące dla 7000 widzów. Między trybunami I i II były padok. Konie były tam wprowadzane ze stajni tunelem. Na terenie służewieckich Wyścigów zbudowano murowane stajnie z padokami i karuzelami dla 800 koni, mieszkania dla pracowników, parking na 2000 samochodów, wieżę ciśnień i magazyny (w tym zbożowy z zapasami 550 ton ziarna). Tor o długości 2300 metrów do wyścigów płaskich miał szerokość $50 \mathrm{~m}$, wewnątrz toru było miejsce na zawody z przeszkodami. Dla dobrego skomunikowania z centrum miasta, przedłużono linię tramwajową ze śródmieścia (do przystanku Wyścigi), planowano poprowadzenie kolejki wąskotorowej. Tor Służewiecki w Warszawie, położony miedzy ulicami Puławska, Wyścigową, Bokserską i Kłobucką był przed wybuchem II Wojny Światowej największym i najbardziej nowoczesnym obiektem sportowym tego typu. Można tez śmiało dodać, że najpiękniejszym i najbardziej eleganckim, 
otoczonym wspaniałą zielenią parku angielskiego (obecnie obszar 220 ha, jaki zajmują tory, jest wpisany do rejestru zabytków, jako 'zielony zabytek'). Modernistyczna ('okrętowa') architektura trybun, ponadczasowa funkcjonalność zespołu, wzbudzają niezmiennie zachwyt odwiedzających, pomimo bardzo wyraźnych potrzeb remontowo-modernizacyjnych. Otwarty w czerwcu 1939 r. tor służył Warszawiakom tylko kilka tygodni. W czasie II wojny światowej tory służyły jako lotnisko wojskowe dla okupanta, po wojnie zostały oddane do użytku w 1946 r., z krótką przerwą funkcjonują nieprzerwanie do chwili obecnej (ryc. 17) [Mórawski 1998, 2007; Olszewski 1986].

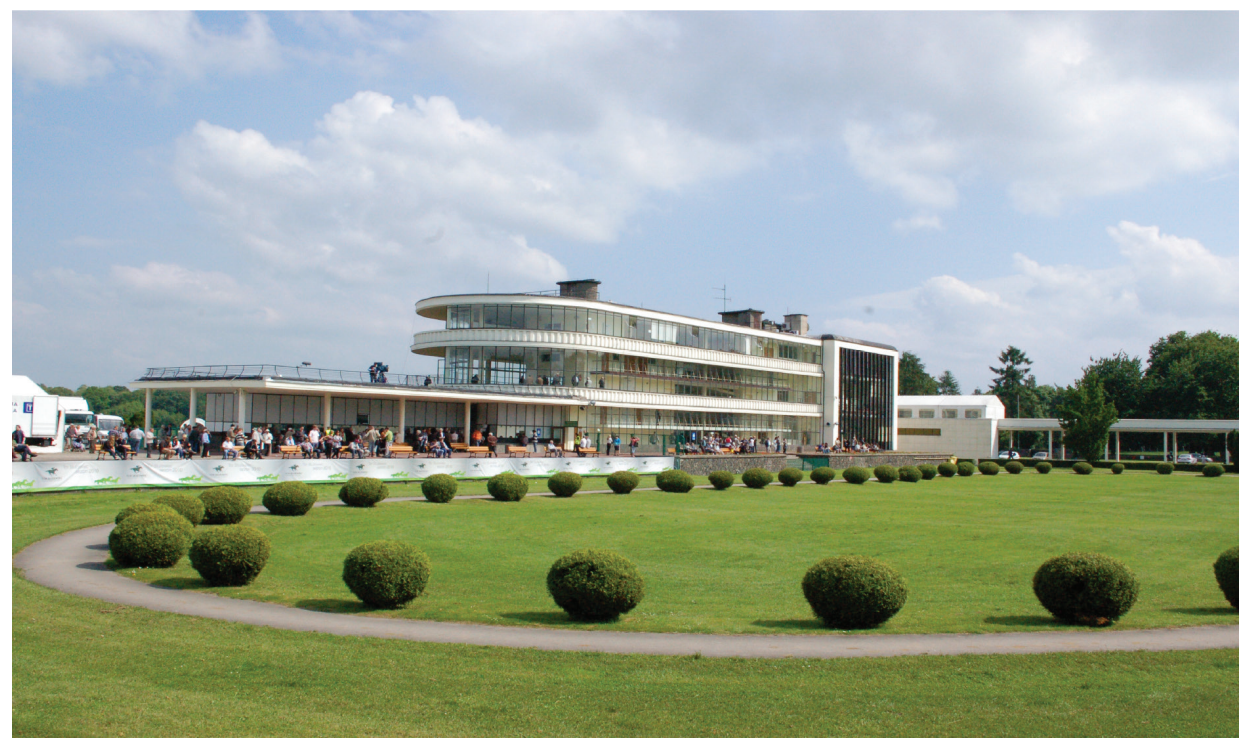

Ryc. 17. Tory Wyścigów Konnych, Służewiec Warszawa, widok współczesny Obiekt wzniesiony w 1939 (proj. Zygmunt Plater-Zyberk)

Źródło: Fot. (autor nieznany, 2015), archiwum cyfrowe fotografii fotopolska.eu [Domena Publiczna]

Rok 1923 to początki gry w golfa w Polsce. Przy ulicy Bartyckiej w Warszawie powstało pierwsze 9-dołkowe pole golfowe. Przed wybuchem II wojny światowej powstały kolejne - w Powsinie pod Warszawa, Gdańsku, Łańcucie i Szczawnie Zdroju. Żadne z nich po zakończeniu wojny nie zostało reaktywowane, pierwsze otwarte $\mathrm{w}$ powojennej Polsce pole golfowe było nowym obiektem zbudowanym w Rajszewie pod Warszawa, dopiero w 1993 r.

Sukcesy polskich tenisistów w okresie II RP (Józef Hebda, Jadwiga Jędrzejowska, Ignacy Tłoczyński) przyczyniły się do znacznej popularyzacji tej dyscypliny sportu. Sekcje tenisowe powstawały przy istniejących klubach sportowych, oficerskich kasynach i klubach wojskowych, eleganckie domy klubowe stały się wytwornymi miejscami, skupiającymi życie towarzyskie w dużych miastach, w tym w Warszawie, gdzie w wielu parkach miejskich zakładano korty [Tarasewicz 1998]. 
Niepewna sytuacja, a wkrótce wybuch wojny, stanęły na przeszkodzie planom budowy kolejnych obiektów sportowych. Tylko w samej Warszawie miał powstać Park Sportów Wodnych, Dom Sportowy AZS nad Wisłą z krytą i otwartą pływalnią, boiskami i salą sportowa, przystanią i hangarami na łodzie oraz rozległym tarasem do kąpieli słonecznych (projekt Marka Łokciowskiego). Miała też w Warszawie powstać kryta ujeżdżalnia koni (w rejonie Agrykoli) o wymiarach 120 m x 60 m i druga mniejsza 20 m x 60 m, z trybunami i stajniami. Do rozpoczętych i nieukończonych inwestycji należały stadion klubu 'Warszawianka' przy ulicy Wawelskiej (wówczas Uniwersyteckiej) w Warszawie oraz Park Sportowy w Fortach Szczęśliwice, którego inwestorem miał być magistrat warszawski. Teren sportowy na terenie Fortu Szczęśliwice miał obejmować stadion z trybunami na 40000 widzów, pływalnię, z trybunami na 1200 widzów, korty tenisowe, strzelnicę sportową boiska do ćwiczeń, tor kolarski (projekt Pracowni Architektonicznej B-ci Łęczyckich, 1928). Należy dodać, że w planie regulacyjnym rozwoju Warszawy planowano budowę kilkudziesięciu nowych boisk sportowych [Osmólski, Jeziorkowski 1928].

W okresie międzywojennym obiektom sportowym towarzyszyły projekty plastyczne (rzeźba, freski, mozaiki). Przy klubie jachtowym 'Syrena' nad Wisłą stal pomnik Syrenki. Intencją wystawy zorganizowanej w 1938 r. w Warszawie 'Sport w Sztuce' było wzbogacenie architektury freskami, płaskorzeźbami i rzeźbami, a także sztuką ludowa, rękodziełem. Ta tendencja ścisłych związków architektury sportowej i wybitnych dzieł sztuki była kontynuowana w architekturze sportowej także po zakończeniu II wojny światowej, przykładem są rzeźby przed Stadionem X-lecia w Warszawie, KS ‘Polonia’ przy ulicy Konwiktorskiej.

Warto też zwrócić uwagę na różnorodne nazewnictwo obiektów sportowych w tamtym okresie, bardzo odmienne od współczesnego. Na przykład w polskiej literaturze przedmiotu z XIX i pierwszej połowy XX w. autorzy używali następujących określeń: dla hal gimnastycznych - dom gimnastyczny lub dom piłkowy, dla szkolnej sali gimnastycznej - sala gier ruchowych lub aula, dla boiska szkolnego - plac wychowania cielesnego, dla krytego lodowiska - sztuczna ślizgawka, stadion lodowy lub stadion zimowy, dla boiska sportowego - boisko ruchowe, dla krytej pływalni - dom kąpielowy, dla skate-rink wrotnisko lub wrotowisko (na określenie wrotek - łyżwy kółkowe), dla nazwania nauczycieli wychowania fizycznego - nauczyciel ćwiczeń cielesnych lub wychowawca fizyczny [Kalinowski, Ziemkiewicz 1935; MWRiOP 1936, MWRiOP 1937; Osmólski, Jeziorkowski 1928, Ziętkiewicz 1912]. 


\section{Literatura}

Bogucka M., 1998, Dawna Polska. Narodziny, rozkwit, upadek, Wydawnictwo TRIO, Warszawa. Bogucka M., 2008, Kultura, naród, trwanie. Dzieje kultury polskiej od zarania do 1989 roku, Wydawnictwo TRIO, Warszawa.

Drozdowski M., Zahorski A., 1981, Historia Warszawwy, Państwowe Wydawnictwo Naukowe, Warszawa.

Fiszer K., 1909, Zarys organizacji polskich gimnastycznych Towarzystw sokolich. Zbiór ustaw sokolich, Związek polskich gimnastycznych Towarzystw sokolich we Lwowie, Lwów.

Janiszewska A., 2012, Sport w przedwojennej Warszawie, Wydawnictwo Fundacji Ośrodek Karta, Warszawa.

Kalinowski A., Ziemkiewicz T., 1935, Jak urządzać ślizgawki. Ślizgawki na stawach i boiskach, bieżnie do jazdy szybkiej, boiska hokejowe, Nakładem Koła Wychowawców Fizycznych w Warszawie, Warszawa.

Karpowicz M., 1986, Sztuka Warszawy, Państwowe Wydawnictwo Naukowe, Warszawa.

Koch W., 1996, Style w architekturze, Wydawnictwo Bertelsmann, Warszawa.

Kwiatkowski M., 1984, Architektura [w:] Dzieje Warszawy w latach 1526-1795, Państwowe Wydawnictwo Naukowe, Warszawa.

Kwiatkowski M., 1986, Architektura w latach 1765-1830 [w:] Sztuka Warszawy, Państwowe Wydawnictwo Naukowe, Warszawa, s. 188-232.

Leśniakowska M., 2005, Architektura w Warszawie, Wydawnictwo PHS ARKADA, Warszawa.

Lipoński W., 2012, Historia sportu, Wydawnictwo Naukowe PWN, Warszawa.

Ministerstwo Wyznań Religijnych i Oświecenia Publicznego, 1937, Publiczne Szkoły Powszechne Pierwszego Stopnia. Teren, budynki, sprzęty, MWRiOP, Skład Główny Nasza Księgarnia, S.A. Związku Nauczycielstwa Polskiego, Warszawa.

Ministerstwo Wyznań Religijnych i Oświecenia Publicznego, 1936, Gimnazja Ogólnokształcace. Teren, budynki, instalacje, meble, MWRiOP, Skład Główny Nasza Księgarnia, S.A. Związku Nauczycielstwa Polskiego, Warszawa.

Mórawski K., 1998, Informator „Warszawa”, Stołeczne Biuro Informacji i Promocji Turystycznej, Warszawa.

Mórawski K., 2007, Bomba w górę - 160 lat wyścigów konnych w Warszawie, Wydano staraniem Muzeum na Woli, Warszawa. 
Norwerth E., 1930a, Centralny Instytut Wychowania Fizycznego na Bielanach w Warszawie, Architektura i Budownictwo, 11, s. 426-456.

Norwerth E., 1930b, Budownictwo sportowe w Niemczech, Architektura i Budownictwo, 11, s. 443-444.

Nowakowski T., 1933, Geneza budownictwa sportowego w Polsce, Architektura i Budownictwo, 4, s. 352-357.

Olszewski A.K., 1986, Architektura, malarstwo, rzeźba [w:] Sztuka Warszawy, Państwowe Wydawnictwo Naukowe, Warszawa, s. 382-466.

Ordyłowski M., 1997, Szkice z dziejów kultury fizycznej, Uniwersytet Zielonogórski, Zielona Góra.

Osmólski W., Jeziorkowski H., 1928, Budowa terenów i urządzeń sportowych, Główna Księgarnia Wojskowa, Warszawa.

Pawlikowska-Piechotka A., 2014, Europejskie tradycje rekreacji w mieście, Akademia Wychowania Fizycznego Józefa Piłsudskiego, Warszawa.

Pawlikowska-Piechotka A., Piechotka M., 2017, Dzieje obiektów sportowych w Europie, Akademia Wychowania Fizycznego Józefa Piłsudskiego, Warszawa.

Pawlikowska-Piechotka A., 2019, Jubileusz 90-lecia Akademii Wychowania Fizycznego Józefa Pitsudskiego w Warszawie, MAZOWSZE Studia Regionalne, 31, s. 173-184; DOI: 10.21858/ MSR.31.08.

Pawłowski T., Zieliński J., 2008, Żoliborz - przewodnik historyczny, Wydawnictwo Rosner i Wspólnicy, Warszawa.

Tarasewicz K., 1998, Narodziny tenisa [w:] Tenis Polski ma 100 lat, PSTT, Warszawa.

Tarasewicz K., 2005, Cały wiek w Warszawie, Wydawnictwo Veda, Warszawa.

Tuszyński B., 1986, 100 lat Warszawskiego Towarzystwa Cyklistów, Kolarstwa Polskiego, Wydawnictwo Okolicznościowe Warszawskiego Towarzystwa Cyklistów, Warszawa.

Tyrmand L., 1999, Dziennik 1954. Wersja oryginalna, Prószyński i S-ka, Warszawa.

Watkin D., 2005, A History of Western Architecture, Laurence King Publishing, London.

Zięcikowski A.E., 1912, Najnowszy Ilustrowany Przewodnik po Warszawie i Okolicach, Skład Główny Gebethnera i Wolffa, Warszawa. 


\section{Historical sports facilities of Warsaw as an asset for contemporary tourism}

Part I: from the Middle Ages until the outbreak of World War II

\section{ABSTRACT}

The history of Warsaw's sports facilities is inscribed in the fortunes of the city and constitutes a document of its cultural heritage. For several hundred years, the development of individual sports disciplines practised in Warsaw has been accompanied by investments in sports. Also, the evolution of sports facilities construction is visible. Thus, the history of Warsaw sports architecture covers a period of about seven hundred years: from the Middle Ages to the present day. It consist of both buildings erected for the needs of great sports events, such as racetracks and modern stadiums, as well as sports facilities accompanying the education or everyday recreation of the city's inhabitants.

Both those facilities that have survived to our times, and those that no longer exist, are an important document of the city's history, a symbol of its identity, and can constitute the foundation for the development of cultural tourism in Warsaw, based on tangible values (preserved objects) and intangible ones (historical memory).

Key words: Warsaw, sports facilities, monuments, cultural tourism 


\section{HISTORYCZNE OBIEKTY SPORTOWE WARSZAWY JAKO WALOR TURYSTYKI WSPÓtCZESNEJ... Anna Pawlikowska-Piechotka, Maciej Piechotka}

Anna Pawlikowska-Piechotka, prof. dr hab. inż. arch. - architekt i urbanista, w latach 2004-2014 profesor wizytujacy na University College Birmingham (Wielka Brytania), Charles University of Prague (Czechy), University of Lahti (Finlandia), University of Saragossa (Hiszpania), University of Evora (Portugalia), University of Viseau (Portugalia), Holar University (Islandia). W swoich badaniach koncentruje się na wykorzystaniu dziedzictwa kulturowego dla zrównoważonego rozwoju turystyki i odpowiedzialnego planowania przestrzeni turystyki, sportu i rekreacji. Uczestniczyła w kilku międzynarodowych projektach badawczych (Niemcy, Szwecja, Holandia, Wielka Brytania, Polska, Turcja); jest autorem ponad dwustu publikacji naukowych, w tym kilku monografii, tekstów opublikowanych w języku angielskim, niemieckim, polskim i serbskim; współautor kilkudziesięciu planów architektonicznych i urbanistycznych (zrealizowanych w Polsce, Niemczech, Nigerii i Libii) oraz wzorów użytkowych obiektów rekreacyjnych dla osób niepełnosprawnych - formalnie zarejestrowanych w Urzędzie Patentowym RP.

Kontakt: Akademia Wychowania Fizycznego Józefa Piłsudskiego w Warszawie;

e-mail:anna.piechotka@gmail.com

Anna Pawlikowska-Piechotka, Prof., PhD Eng, DSc, Arch. - architect and urban planner, in 2004 - 2014 a visiting professor at University College Birmingham (United Kingdom), Charles University of Prague (Czech Republic), University of Lahti (Finland), University of Saragossa (Spain), University of Evora (Portugal), University of Viseu (Portugal), Holar University (Iceland). Focuses in her research on the usage of cultural heritage for sustainable tourism and responsible planning for tourism, sport and recreation. Participated in several international research projects (Germany, Sweden, Holland, UK, Poland, Turkey). Author of over two hundred scientific publications, including several monographs, papers published in English, German, Polish and Serbian. Co-author of several architectural and urban plans of recreation and tourist space (commissioned in Poland, Germany, Nigeria and Libya) and utility models of recreation facilities for disabled - formally registered in the Polish Patent Office.

Contact: the Józef Piłsudski University of Physical Education in Warsaw;

e-mail:anna.piechotka@gmail.com

Maciej Piechotka, mgr inż. architekt, absolwent Wydziału Architektury Politechniki Warszawskiej. Specjalizuje się w projektach architektonicznych obiektów użyteczności publicznej - w tym obiektów sportowych oraz w architekturze mieszkaniowej. Był przez wiele lat zwiq̨zany z Wojewódzkim Biurem Projektowym WBP ARWO w Warszawie, a następnie z Biurem Projektów BP WARCENT w Warszawie, od kilkunastu lat, od roku 2003 - z architektoniczna pracowniq projektowa przy ECO CLASSIC GROUP w Warszawie. Autor i współautor ponad stu projektów architektonicznych ( $w$ tym zrealizowanych w Libii, Nigerii oraz w Polsce), mający także doświadczenie w pracy naukowo-dydaktycznej (Wydział Architektury Politechniki Warszawskiej, Faculty of Architecture University of Nigeria, Enugu Nsukka). Wieloletni członek Stowarzyszenia Architektów Polskich SARP oraz Izby Architektów Rzeczpospolitej Polskiej IARP (pełniący drugą kadencję funkcję sędziego IARP). Współautor kilku skryptów akademickich, kilkunastu artykułów na temat teorii architektury i planowania zrównoważonego oraz kilku zgłoszonych patentów (urzq̨dzenia dla osób niepełnosprawnych).W uznaniu dorobku został odznaczony tytułem 'Architekta - Twórcy', nadanym przez Ministra Kultury i Sztuki w 2001 r.

Maciej Piechotka, MSc Eng, Architect, graduate of the Warsaw University of Technology Faculty of Architecture. Specialised in architectural designs of public utility buildings - including sports facilities and residential architecture. For many years associated with the Provincial Design Office WBP ARWO in Warsaw, and then with Constructions' Projects Office BP WARCENT in Warsaw. For several years, from 2003, associated with an architectural design studio at ECO CLASSIC GROUP in Warsaw. Author and co-author of over one hundred architectural projects (including ones implemented in Libya, Nigeria and Poland), also experienced in research and teaching (Faculty of Architecture, Warsaw University of Technology, Faculty of Architecture University of Nigeria, Enugu Nsukka). A long-standing member of the Association of Polish Architects SARP and the Chamber of Architects of the Republic of Poland IARP (holding the second term of office of IARP judge). Co-author of several academic scripts, several articles on the theory of architecture and sustainable planning, as well as several patents (devices for the disabled). In recognition of his achievements, he was awarded the title of "Architect-Creator" by the Minister of Culture and Art in 2001. 